Board of Governors of the Federal Reserve System

International Finance Discussion Papers

Number 656

December 1999

\title{
SOURCES OF ECONOMIC FLUCTUATIONS IN LATIN AMERICA AND IMPLICATIONS FOR CHOICE OF EXCHANGE RATE REGIMES
}

\author{
Shaghil Ahmed
}

NOTE: International Finance Discussion Papers are preliminary materials circulated to stimulate discussion and critical comment. References in publications to International Finance Discussion Papers (other than an acknowledgment that the writer has had access to unpublished material) should be cleared with the author or authors. Recent IFDPs are available on the Web at www.bog.frb.fed.us. 


\title{
SOURCES OF ECONOMIC FLUCTUATIONS IN LATIN AMERICA AND IMPLICATIONS FOR CHOICE OF EXCHANGE RATE REGIMES
}

\author{
Shaghil Ahmed*
}

\begin{abstract}
This paper studies the sources of economic fluctuations in three key Latin American countries (Argentina, Brazil, and Mexico) using a dynamic panel model, distinguishing between external and domestic shocks. The primary motivation is to examine the implications for the choice of monetary and exchange rate regimes, including dollarization. The results do not provide a strong, clear case in favor of a particular policy choice. On the one hand, foreign output shocks, including those of the U.S. appear to have a quite limited role in driving output fluctuations in these Latin countries; this absence of common shocks undermines the case for a rigidly fixed exchange rate regime. On the other hand, the historical experience of these countries indicates that real exchange rates are not very responsive to external shocks, in general, and that exchange rate depreciations tend to be contractionary in the short run. This suggests that rigidity of exchange rates may not be as costly for these countries as economic theory leads us to expect. Although the historical experience of these countries is certainly relevant, the caveat that it is characterized by several failed fixed exchange rate regimes, thereby making it a less than ideal testing ground for evaluating a pure floating exchange rate system, should be noted.
\end{abstract}

Keywords: economic fluctuations, latin america, exchange rate regimes, dollarization.

*Division of International Finance, Board of Governors of the Federal Reserve System. Email: shaghil.ahmed@frb.gov. The author thanks Peter Hooper, David Howard, Steve Kamin, and John Rogers for very helpful comments. The views in this paper are solely the responsibility of the author and should not be interpreted as reflecting the views of the Board of Governors of the Federal Reserve System or of any other person associated with the Federal Reserve System. 


\section{Introduction and Summary}

This paper examines the sources of economic fluctuations in key Latin American countries (Argentina, Brazil, and Mexico) using a dynamic panel model. Specifically, we are interested in the extent to which short-term fluctuations in output, inflation, and the real exchange rate in these countries are driven by external shocks (terms of trade, foreign output, and U.S. real interest rate shocks) versus other economic disturbances (which we identify as real exchange rate, domestic output, and domestic price level shocks).

Since we control for the effects that the external variables have on the domestic economy, presumably these other disturbances largely represent domestic influences, and hence we label them "domestic" shocks. Nonetheless, it should be recognized that classifying shocks to variables such as the real exchange rate as domestic or external is inherently difficult, and the possibility remains that part of what we call domestic shocks represents some other relevant external factors that are not captured by our terms of trade, foreign output, and U.S. real interest rate variables. ${ }^{1}$

The relative contribution of external factors in explaining business fluctuations in emerging-market economies is an important issue for both positive and normative reasons: it has implications for the relative merits of alternative models of open economies as well as the design and selection of appropriate macroeconomic policies in these countries. Our specific primary interest here is in examining the implications of our results for the choice of appropriate exchange rate regimes in these economies, a topic of much recent debate. To this end, we address the following questions: (1) To what extent do the results support the hypothesis that the U.S. and these countries form an optimal currency area? That is, are the business cycles of these Latin countries related to those of the U.S. in such a way that the monetary policy being pursued

\footnotetext{
${ }^{1}$ Also, it would seem desirable to directly control for the effects that domestic monetary policy changes might have had on economic fluctuations in these Latin countries, perhaps by including domestic real interest rates in our system. However, in our sample period, which includes periods of hyperinflation, with the consequent volatility of expected inflation, the $e x$ post domestic real interest rate is probably not a good proxy for the ex ante domestic real interest rate.
} 
by the U.S. at any particular time would happen to be the right policy for these countries also?

(2) Historically, have recessions in these countries been caused more by adverse external shocks or adverse domestic shocks? (3) Historically, have real exchange rate movements in these countries been important in promoting appropriate adjustments of the economy to external and domestic shocks?

A near-consensus seems to be emerging in the literature that emerging market countries should consider only "polar" regimes of a fully floating or rigidly fixed exchange rate, rather than more mixed systems such as adjustable pegs. However, it remains controversial which of the two polar regimes-rigidly fixed or fully floating-is more appropriate. The answers to the questions posed above would seem to be at least some of the relevant key considerations in making the right choice. Although there has been no dearth of recent debate on these questions in policy circles, there has been relatively little formal empirical analysis that could be used to provide a quantitative assessment.

The empirical results of this paper suggest the following answers to these questions:

(1) Business cycles of the Latin countries we focus on do not appear to be driven by output shocks in the countries they export to, including the U.S. ${ }^{2}$ The above result implies that it is unlikely that U.S. monetary policy being pursued at any particular time would happen to be the appropriate monetary policy for these countries also.

(2) The external shocks we explicitly model account for a significant, but relatively small fraction (about 20 percent) of output fluctuations in the Latin countries studied here. Our results also appear to indicate that devaluations are contractionary, in that negative shocks to the real exchange rate significantly depress output in these countries. This result seems to go against conventional economic theory; one possible explanation is that devaluations in these countries have tended to occur in crisis situations, and thus are

\footnotetext{
${ }^{2}$ However, U.S. real interest rate shocks do appear to cause cyclical fluctuations in output in these countries, although the contemporaneous response seems to be perverse; on impact, a rise in U.S. real interest rates expands Latin output, but subsequently the response is negative as we might expect.
} 
usually accompanied by domestic austerity measures and capital outflows, which likely depress output directly. The above results suggest that recessions in these countries have largely been a result of domestic factors and policies, which show up as negative real exchange rate and adverse domestic output shocks in our empirical model.

(3) In order for real exchange rate movements to promote appropriate adjustment of the economy to shocks, we should observe that the currency depreciates in real terms in response to adverse external shocks and, that the exchange rate depreciation in turn has an expansionary effect on the economy over time. There is only weak evidence that the real exchange rate depreciates significantly in response to adverse external terms of trade and U.S. real interest rate shocks. Moreover, as already noted, the results also indicate that real exchange rate depreciations have been contractionary in the short run. Together, these two results suggest that, historically at least, real exchange rate movements have not been an important channel through which appropriate adjustments of these Latin economies to shocks have occurred. These results are subject to the caveat that the experience of these countries over the sample period has been characterized by a mixture of different exchange rate regimes, including several failed experiments with fixed exchange rate regimes. It is possible that in a different regime, representing a more textbook-style floating exchange rate system, the real exchange rate would play a more appropriate equilibrating role.

The remainder of the paper is organized as follows: section 2 provides a selective review of the previous related literature; section 3 lays out the empirical model that is estimated and discusses the data and the empirical methodology; section 4 presents and interprets the empirical results; and section 5 concludes.

\section{Selective Review of Previous Literature}

This study is related to two main lines of inquiry: the empirical literature on the sources of business fluctuations in developing economies and the literature on exchange rate regimes. In the interest of brevity, the review of the previous work here is very selective, especially given the 
breadth of the literature on fixed versus flexible exchange rate systems.

The stylized facts of macroeconomic fluctuations in developing countries have been documented in a recent study by Agenor, McDermott, and Prasad (1999). For our purposes, their two most relevant results are that: (1) output fluctuations in developing countries tend to be positively related to those in industrial countries, and (2) these output fluctuations are also contemporaneously positively related with world real interest rate changes. ${ }^{3}$

Although documenting empirical regularities can be suggestive of the types of fundamental economic disturbances that impinge on these economies, it a far cry from actual identification of these shocks. There are not many empirical studies of macroeconomic fluctuations in developing countries that attempt to identify the fundamental economic disturbances in models which allow for a rich enough classification of these shocks. Of the limited number of studies, the most relevant for our purposes is Hoffmaister and Roldos (1997). In that study the authors use panel data from a number of Asian and Latin American countries to consider the effects of various shocks on output growth, inflation and real exchange rates. Their study is comprehensive in its list of shocks, including world real interest rate, terms of trade, domestic fiscal, and domestic supply shocks. The authors' main conclusion using long-run identification restrictions, is that domestic country-specific aggregate supply shocks are by far the most important source of output fluctuations in these countries.

For the questions of interest here, there are two main problems with the HoffmaisterRoldos study. First, their results depend crucially on the strong assumptions that underlie the long-run identification restrictions in their model. Second, more importantly, they do not allow for a foreign output shock in their model. The optimum currency literature (discussed below), for example, tells us that knowledge about shocks countries share in common should be an important input into the decision of whether to give up one's own currency. Our empirical specification allows for the possibility of such common shocks.

${ }^{3}$ However, Larsen and Aziz (1997) earlier have argued that since the mid-1980s, there has been an apparent decoupling in the business cycles of the ASEAN countries and those of the industrial countries. 
Some other studies have also distinguished between external and domestic shocks for developing countries. Montiel (1997) and Reinhart (1995) examine the effects of external factors such as world inflation and the relative price of exports and imports on developing countries, but the analysis is limited to the effects on the real exchange rate in the former paper and the on trade flows in the latter. Edwards and Vegh (1997) demonstrate how, in a small open economy setting, the empirical effects of both domestic and external shocks gets magnified through the bank credit channel. However, the only external variable they consider is the world real interest rate, and their analysis is also limited to Chile and Mexico. Fackler and Rogers (1995) analyze the role of fiscal, real, monetary, exchange rate, and asset disturbances on output and inflation in Bolivia and Brazil, but they do not explicitly consider the role played by external shocks relative to domestic shocks in driving business cycles.

The effects of one of the main external shocks facing developing countries, namely terms of trade shocks, are also analyzed in detail by Mendoza (1995). Using simulations from a calibrated general-equilibrium small open economy model, he finds that terms of trade can account for up to half of real GDP fluctuations. One of the motivations of this study is to see to what extent this result applies to estimated models as well, and what implications it has for the debate on the choice of exchange rate regimes.

The importance of separating external and domestic factors in empirical work analyzing the choice of exchange rate regimes is also underscored in Kamin and Babson (1999). They find that devaluation crises in Latin America have been primary a result of domestic policy and domestic economic factors, which suggests that adoption of a rigidly fixed exchange rate may not be too costly in terms of diminished ability of the economy to respond to external shocks. They use a different, but complementary, empirical methodology, focusing on an "early warning systems" approach, rather than the VAR-type approach adopted here. ${ }^{4}$

Next we turn to the literature that more directly focuses on exchange rate regimes, of

${ }^{4}$ Specifically, they use a probit model to estimate the probability of a currency crisis as a function of a broad set of domestic and external variables. 
which the work on optimal currency areas (OCAs) is the most relevant for this paper. The classical literature on OCAs (for example, Mundell [1961], McKinnon [1963], and Kenen [1969]) identifies the main costs of joining a currency bloc as the loss of flexibility a separate currency provides in responding to adverse shocks--including counter-cyclical monetary policy, exchange rate adjustment, and lender-of-last-resort capacity-and loss of seigniorage. ${ }^{5}$ Countries for which the costs of giving up flexibility are low are regarded as being part of a natural OCA. One of the main factors affecting these costs of giving up exchange rate flexibility is the nature of the shocks hitting an economy. If a country shares common (symmetric) shocks with the other currency bloc countries, it may have less need for an independent monetary policy and a flexible exchange rate than if it had to respond primarily to its own idiosyncratic (asymmetric) shocks. Therefore, in assessing whether the Latin countries should switch to an extremely rigid fixed exchange rate system by giving up their own currency, it is important to know the extent to which they share common shocks with the potential anchor currency country, the United States. ${ }^{6}$

Even if the costs of giving up one's own currency are not low, countries may still prefer to do so if the benefits of doing so are sufficiently large. Besides the traditional benefit of lower transaction costs associated with trade in goods and assets, other benefits that the recent literature has emphasized are credibility effects and, resulting from that, a permanently lower inflation rate. ${ }^{7}$ These benefits are generally associated with a fixed exchange rate system, with currency

${ }^{5}$ The classical papers and subsequent literature evaluating the traditional criteria are also surveyed in Eichengreen (1994) and Masson and Taylor (1993).

${ }^{6}$ As is well known from the OCA literature, the costs are also affected by cross-border factor mobility and factor price flexibility. Countries with high factor mobility and high factor price flexibility may have less need for exchange rate and monetary policy flexibility in adjusting to asymmetric shocks.

${ }^{7}$ In a provocative recent paper, Eichengreen and Hausmann (1999) (EH) argue that there is another very important benefit to giving up their currency altogether for emerging market economies. Such countries suffer from what they refer to as "original sin", the inability to borrow long-term in local currency either from abroad or domestically. Accordingly, exchange rate depreciations in such economies tend to create currency and maturity mis-matches in balance sheets, which contribute substantially to financial fragility in these economies. According to $\mathrm{EH}$, these balance sheet problems can be got rid of by giving up the domestic currency, but it is unclear how dollarization would get rid of maturity mis-matches, even if it solved the problem of currency mis-matches. 
board and currency bloc arrangements, seen as enhancing the benefits, as they are specially rigid form of fixed exchange rate regimes. For example, Ghosh et al (1997) argue that inflation is both lower and more stable under pegged exchange rate regimes, although it comes at the cost of higher real volatility. Moreover, Ghosh, Gulde, and Wolfe (1998) make the case that average inflation under currency board arrangements is about 4 percentage points lower compared to more adjustable pegged rates, with the bulk of the difference resulting from credibility and confidence effects. This suggests such benefits under a policy in which a government gives up its own currency altogether may even be greater.

Our paper is well suited to analyze the inflationary impact of a real exchange rate shock that emanates from domestic factors alone, since we separately keep fixed the effect of the external factors on the real exchange rate. This will give some idea how much the disinflationary benefit of moving to more rigid exchange rate systems-which presumably limits the size of real exchange shocks-might be in these countries.

With respect to the question of whether exchange rate adjustments have historically provided appropriate adjustments in Latin America to external and domestic shocks, there are reasons to suspect that such adjustments may play less of an equilibrating role in developing countries than they do perhaps in industrial countries. Partly, as argued by Edwards and Savastano (1999) for example, this is because of a dearth of episodes of pure floating exchange rates in those economies. Nonetheless, it is relevant to know what role real exchange rate adjustments have played in the past, even while being careful not to draw strong conclusions from this about what role they could play in principle.

Empirically, for Mexico, Kamin and Rogers (1997) find that devaluations tend to be associated with economic contractions, while real appreciations are associated with economic expansions. This suggests that exchange rate adjustments in Mexico in the past may have played a questionable equilibrating role. Moreover, Kamin-Rogers cannot identify a positive, long-run real causal effect of a devaluation on output, even after controlling for a number of factors that might be responsible for causing the seemingly perverse raw correlation. One goal of our paper 
is to see whether this result is unique to the Mexican experience or also applies to other Latin countries, particularly Argentina, where there appears to be more sentiment for dollarization than in other major Latin countries.

\section{Empirical Model, Methodology, and Data}

The empirical methodology is to estimate a six-variable vector error-correction model (VECM) using annual data from Argentina, Brazil, and Mexico over the period 1981-1998 in a panel setting. The choice of annual data is largely dictated by a lack of quarterly terms of trade series for the Latin countries going back over a significant length of time.

A VECM is a vector auto-regressive (VAR) model in differences, augmented to include the lagged levels of some variables to allow for the possibility of a long-term stable relationship between the levels of the variables (cointegration). Of the six variables we consider, three (the

terms of trade, foreign output, and the U.S. real interest rate) are determined only by external factors and are labeled "external variables," while the remaining three (the real exchange rate, output, and the price level) are influenced by domestic factors in addition to the external variables, and are labeled "domestic variables."

Specifically, we estimate the following dynamic, structural system of equations:

$$
A(0) \Delta X_{i t}=A(L) \Delta X_{i, t-1}+\beta \alpha^{\prime} X_{i, t-1}+u_{i t}
$$

where $X$ is the vector of variables included in the model, $A(0)$ is the matrix of contemporaneous interactions, $A(L)$ is a matrix of lay polynomials, $\beta$ and $\alpha$ are matrices of fixed parameters, $u$ is a vector of i.i.d. structural errors, and subscripts $i$ and $t$ refer to the country and time period, respectively. Note that $\alpha^{\prime} X$ represents the long-term (cointegration) relationships (if any) among the variables, and $\beta$ represents the speeds of adjustments toward the long-run paths. Intercepts

${ }^{8}$ It might seem strange to classify a variable such as the real exchange rate as a "domestic" variable. Therefore, it is important to re-iterate that, in our terminology, "external" variables are those that are determined only by rest of the world conditions, which the domestic economy takes as given (the small open economy assumption), whereas "domestic" variables are those that are influenced by domestic factors in addition to the rest of the world conditions. 
and fixed effects are included in the empirics, but have been suppressed here for convenience.

It will be useful to partition $\triangle X$ into "external" and "domestic" variables along the lines discussed earlier and also to partition the structural disturbances correspondingly into external and domestic shocks. Thus,

$$
\Delta X=\left(\begin{array}{c}
\Delta X_{1} \\
\hline \Delta X_{2}
\end{array}\right)=\left(\begin{array}{c}
\Delta t o t \\
\Delta y f \\
u s r \\
\hdashline \Delta r e r \\
\Delta y \\
\pi
\end{array}\right) ; \quad u=\left(\begin{array}{c}
\varepsilon \\
\eta
\end{array}\right)=\left(\begin{array}{c}
\varepsilon_{1} \\
\varepsilon_{2} \\
\varepsilon_{3} \\
-\frac{\eta}{\eta_{1}} \\
\eta_{2} \\
\eta_{3}
\end{array}\right)
$$

where the external stationary variables (represented by $\Delta X_{I}$ ) are the rate of change of the terms of trade (Atot), foreign output growth ( $\Delta y f$ ), the U.S. real interest rate (usr), and the domestic stationary variables (represented by $\Delta X_{2}$ ) are the rate of appreciation of the real exchange rate (Arer), domestic output growth $(\Delta y)$, and domestic inflation $(\pi)$. The vector $\varepsilon$ represents the vector of external shocks (the terms of trade, foreign output, and U.S. real interest rate shocks, respectively); and the vector $\eta$ represents the vector of domestic shocks (a domestic real exchange rate shock, a domestic output shock, and a domestic price level shock, respectively)-i.e. after accounting for the influence of the external shocks on these variables.

It is well-known that the assumptions that the fundamental economic disturbances in the vector $u$ are i.i.d. and, therefore, have a diagonal covariance matrix do not fully identify structural models like (1). To meaningfully analyze the effects of various shocks, some further restrictions have to be imposed. We achieve this by the fairly common method of imposing a contemporaneous recursive causal ordering on the variables (the Choleski decomposition), which implies a lower-triangular $A(0)$ matrix which, conforming to the partition of external and domestic variables made earlier, we denote by: 


$$
A(0)=\left(\begin{array}{c:ccc:ccc}
A_{11}(0) & A_{12}(0) \\
\hdashline A_{21}(0) & A_{22}(0)
\end{array}\right)=\left(\begin{array}{ccc:ccc}
1 & 0 & 0 & 0 & 0 & 0 \\
a_{21} & 1 & 0 & 0 & 0 & 0 \\
a_{31} & a_{32} & 1 & 0 & 0 & 0 \\
\hdashline a_{41} & a_{42} & a_{43} & 1 & 0 & 0 \\
a_{51} & a_{52} & a_{53} & a_{54} & 1 & 0 \\
a_{61} & a_{62} & a_{63} & a_{64} & a_{65} & 1
\end{array}\right)
$$

The $A(0)$ matrix in (3) implies the following contemporaneous causal ordering of the variables: For the external variables, causality runs from terms of trade to foreign output to the U.S. real interest rate, reflected in the lower triangularity of $A_{l l}(0)$. We put the terms of trade and foreign output before the U.S. real interest rate in the causal ordering to allow for the possibility that U.S. monetary policy may react to these variables within the year; the estimated contemporaneous interactions under this ordering are consistent with the interpretation that unexpected increases in U.S. output elicit a tightening of U.S. monetary conditions in response. Putting U.S. real interest rates last in the causal ordering of the three external variables also implies, however, that foreign output, which includes U.S. output, does not react to U.S. monetary policy contemporaneously. The identification assumption that output does not react to monetary policy changes contemporaneously is often made in studies of U.S monetary policy employing monthly or quarterly data; however, this assumption may be overly strong when using annual data, as in this paper. Therefore, it should be noted that the results are the same (at least qualitatively) if we put the U.S. real interest rate earlier in the causal ordering.

With respect to the domestic variables, it is assumed first that the external variables are causally prior to them, which just reflects the small open economy assumption and is the source of the $A_{12}(0)$ matrix being the null matrix. ${ }^{9}$ Also, within the domestic variables, we assume that the contemporaneous direction of causation goes from the real exchange rate to domestic output to the domestic price level, which translates into a lower triangular $A_{22}(0)$. While putting the

\footnotetext{
${ }^{9}$ The small open economy assumption entails further restrictions as well, in that even lagged values of domestic variables should not feed back into the external variables. However, since these restrictions are not needed for identification they are not imposed. They are testable restrictions.
} 
price level last in the causal ordering seems reasonable, it is more controversial what the direction of contemporaneous causality is between the real exchange rate and output. Certainly, changes in exchange rate policy, which could be one source of domestically driven shocks to the real exchange rate, can affect output. But economic theory predicts that changes in output, related to changes in domestic productivity relative to foreign productivity, affect the real exchange rate as well. Since this latter effect is more likely to be a longer run phenomenon, we put the real exchange rate ahead of output in the causal ordering. However, in order to examine the sensitivity of the results to this assumption, we have also estimated an alternative model in which the domestic output is causally prior to the real exchange rate. This alternative model did not change the main thrust of the results reported here.

Since the external variables are causally prior to the domestic variables, the computed shocks to the real exchange rate, domestic output, and the price level variables have already accounted for the effects that the external shocks (the terms of trade, foreign output, and the U.S. real interest rate shocks) have on these variables. ${ }^{10}$ Given this, it is likely that our measured shocks to the real exchange rate, output, and the price level represent largely the influence of domestic factors, and, hence, we call them domestic shocks. The possibility remains, though, that they include the influence of some other external factors that are not captured by the external variables we explicitly model.

Next we turn to the form that the error correction terms in the system (1) might take. Economic theory predicts that the long-run path of the levels of the real exchange rate, domestic output, foreign output, and the terms of trade should be closely linked. Specifically,

$$
\alpha^{\prime} X_{i, t-1}=\operatorname{rer}_{t-1}-\left(\alpha_{1} y_{i, t-1}-\alpha_{2} y f_{i, t-1}\right)-\alpha_{3} t t_{i, t-1}
$$

\footnotetext{
${ }^{10}$ In particular, the work of Montiel (1997) for the ASEAN countries and of De Gregorio and Wolf (1994) for fourteen OECD countries finds terms of trade movements to be important empirical determinants of real exchange rate movements. Therefore, we consider it specially important to control for shocks to terms of trade in order to properly identify shocks to the real exchange rate that might be arising purely from domestic factors and policies. In practice, we find that terms of trade do not matter as much for the real exchange rate in Latin America as the above studies have found for industrial OECD and developing ASEAN economies.
} 
where $r e r$ is the real exchange rate (recall a rise reflects a real appreciation of the domestic currency), $y$ is domestic output, $y f$ is foreign output, tot represents the terms of trade, with all these variables being in logs, and $\alpha_{1}, \alpha_{2}, \alpha_{3}$ are positive parameters. To interpret the long-run relationship reflected in (4), consider a positive domestic productivity shock, which will translate into increased domestic output in the long run. If productivity enhancements are biased toward the production of traded goods (the typical assumption), then there will be a relative excess supply of traded goods, which will bid up the relative price of non-traded goods at home, thereby causing a real appreciation of the domestic currency. Conversely, a foreign productivity shock increases foreign output, and causes an increase in the relative price of non-traded goods in the foreign country, thereby depreciating the domestic currency in real terms. If $\alpha_{1=} \alpha_{2}$, the terms in parentheses in (4) reduce to the difference of outputs, implying that the real exchange rate responds positively to productivity differentials across countries-the "Balassa-Samuelson" effect. However, if the countries' economic structures are not exactly identical, e.g. if countries have different abilities to use the technology, then $\alpha_{1}$ need not equal $\alpha_{2}$.

Also, in models with more than one traded good, the long-run path of the real exchange rate would also be directly influenced by the long-run path of the terms of trade. An improvement in the terms of trade will likely lead to a real appreciation of the domestic currency, as it effectively acts like a shift out in the production possibilities frontier of the exported good.

Our annual observations do not provide enough of a span of data to be able to estimate the cointegrating relation in (4) accurately. Therefore, in estimating (1), we include the oncelagged levels of the real exchange rate, domestic output, foreign output, and the terms of trade in an unrestricted manner; which allows for the possibility of a cointegrating relation like (4) but leaves its parameters unspecified (that is, $\alpha$ and $\beta$ are not separately identified).

\section{Data}

The dynamic panel is estimated with annual data from 1981-1998. The panel consists of three major Latin American countries: Argentina, Brazil, and Mexico. For each country: domestic output is real GDP, the domestic price level is the consumer price index (CPI), foreign 
output is an export-weighted (using weights from 1998 data) aggregate of the real GDP of the eight largest export markets; the real exchange rate is the Federal Reserve Board's broad (covering 35 countries) CPI-based real exchange rate index (with an increase indicating a real appreciation of the domestic currency); and the terms of trade are the ratio of export to import prices, taken from the Inter-American Development Bank database. The U.S real interest rate is a monthly average of the 30-day treasury bill rate less the month-ahead ex post consumer price inflation rate, expressed as an annualized rate. This variable obviously does not vary across the three cross-sections in the panel. Plots of the data are presented at the end of the paper.

\section{Results}

The identification restrictions given in (3) are used to retrieve the structural dynamic panel system given by (1) from the reduced-from estimated VECM.

Once the structural model is retrieved, impulse responses and variance decompositions are computed. The impulse responses present the dynamic responses of the variables to one standard-deviation shocks to the structural disturbances; the variance decompositions present the percentage of the error variance at various forecast horizons that is attributable to each of the individual shocks. In order to see if there have been particular episodes in which the relative role of external versus domestic factors has been widely different than in the overall variance decompositions, we also present the historical decompositions. For each year and each country, these present the deviation of a particular variable's value from its baseline forecast (based on data from 1984 and before) due to the accumulation of all shocks; this is compared with the variable's deviation from the baseline forecast due to the accumulation of external shocks alone.

The impulse responses are plotted in figures 1-6 (with 1 and 2/3 standard deviation bands shown, which roughly correspond to 90 percent confidence intervals ${ }^{11}$; the variance decompositions are presented in tables 1-3; and the historical variance decompositions are shown in figures 7-9. Our discussion of the results here is organized as answers to the specific questions that were posed in the introductory section.

\footnotetext{
${ }^{11}$ Standard errors have been computed using Monte Carlo simulations with 1000 iterations.
} 
Question 1: Are the business cycles of key Latin American countries related to those of the U.S. in such a way that the monetary policy being pursued by the U.S. at any particular time would happen to be the right policy for these countries also?

The two most relevant impulse responses for answering this question are the responses to a foreign output shock (shown in figure 1) and the responses to a U.S. real interest rate shock (shown in figure 2). The variable labels used in the figures are explained in an Appendix immediately following the figures. Foreign output includes U.S. real GDP, with a weight of over 90 percent for Mexico, 35 percent for Brazil, and just under 20 percent for Argentina.

As illustrated in figure 1, a one standard-deviation shock to foreign output growth (which translates into about a percentage point increase in the growth rate) does not have much of an effect on domestic growth until about three years later, when growth increases by about half a percentage point. This means that the level of domestic real GDP does not rise significantly until three years later. Moreover, the variance decompositions in table 1 show that the foreign output shock explains under 3 percent of the forecast error variance of domestic output growth at up to a two-year forecast horizon.

Since the foreign output variable for the Latin countries includes U.S. output as a component, it would be instructive to examine the response of the U.S. real interest rate to a shock to this variable. Figure 1 shows that in response to a percentage point deviation of foreign GDP growth from its baseline, the U.S. real interest rate increases within the year by about 25 basis points; this is consistent with unexpected increases in U.S. output leading to a tightening of U.S. monetary conditions, as we might expect.

Figure 2 shows the responses to a standard-deviation shock to the U.S. real interest rate (which translates into an increase of about $2 / 3$ of a percentage point). Puzzlingly, domestic output growth rises at first. However, one year later this reverses itself with a negative effect on the growth rate of output also of about an eighth of a percentage point, which is in the expected direction. Thus, there appear to be a significant cyclical response of the outputs of the Latin countries in response to U.S. real interest rate changes, but little change after two years. The 
variance decompositions in table 1 suggest that U.S. real interest rates explain 9-15 percent of domestic output growth fluctuations at a zero to two-year horizon.

To sum up, the business cycles of these Latin countries do not appear to be driven by output shocks in the countries they export to, including the United States. Moreover, U.S. real interest rate movements appear to cause short-run fluctuations in these countries, although the contemporaneous response is perverse. These results suggest that it is unlikely that the U.S., Argentina, Brazil, and Mexico form an OCA. ${ }^{12}$ Under these circumstances, increasing the rigidity of exchange rate arrangements, e.g. through dollarization (which at least the Argentine government seems to be seriously contemplating), could lead to a situation where U.S. monetary policy changes act as a destabilizing force on these countries; such changes would create unnecessary cyclical fluctuations in output, which these countries would not be able to potentially undo in the absence of an independent domestic monetary policy. ${ }^{13}$ On the other hand, since we do not directly control for domestic monetary policy, we cannot provide direct evidence on whether, in fact, in the past, in those periods in which flexibility of monetary policy has been available, Latin monetary policy has reacted appropriately to asymmetric shocks. But the history of these economies suggests that this is unlikely to have been the case.

\section{Question 2: Historically, have recessions in key Latin American countries been caused} more by adverse external shocks or adverse domestic shocks?

We have already discussed the responses of domestic output to two of the external shocks, foreign output and U.S. real interest rate shocks. The responses to the remaining external

\footnotetext{
${ }^{12}$ This is consistent with the results in Bayoumi and Eichengreen (1994) who identify three regional groupings which face similar underlying disturbances--a Northern European bloc, a Northeast Asian bloc, and a Southeast Asia bloc--but find that Northern American countries or the Mercosur countries do not appear to meet this major criterion of an optimal currency area.

${ }^{13}$ Note that, in the case of Argentina at least, U.S. monetary policy changes are already in large part potentially destabilizing because Argentina's present currency-board-style arrangement is a pretty rigid form of fixed exchange rate regime; however, official dollarization could further the potential for such destabilization. Conversely, it should also be noted that Frankel and Rose (1996) point out that trade and output links across countries--as well as other criteria of an optimum currency area--are endogenous and may not be independent of whether countries are part of a currency union or not.
} 
shock, a terms of trade shock, are displayed in figure 3. A one standard-deviation positive shock to the rate of change of the terms of trade (which translates into an improvement of about 5 percentage points) increases domestic output growth in the short run by about $1 / 2$ a percentage point. The level of output remains significantly elevated for about two years. While these results are plausible, the variance decompositions in table 1 show that the terms of trade shocks explain only about 4-6 percent of the domestic output growth fluctuations at a zero to two-year horizon.

Table 1 also shows that external shocks as a group explain about a fifth of the movements in domestic output growth at a zero to two-year horizon. ${ }^{14}$ If we were able to include an appropriate measure of domestic real interest rates, chances are the contribution of external shocks would have been even less. The historical decompositions in figures 7-9 do indicate that the external disturbances are more important for output fluctuations in some periods than the above results for the full sample suggest (specifically, 1994-97 in Argentina; 1986, 1989-90, 1992, and 1994 in Brazil; and, 1985, 1993, and 1997 in Mexico).

Turning to the impulse responses of the domestic shocks, the effects of a real exchange rate shock are displayed in figure 4. Recall that, since the effects of the three external shocks on the real exchange rate are kept fixed, our measured shock to the real exchange rate probably represents a disturbance to this variable that results from domestic factors, perhaps policyinduced. A one standard-deviation positive shock to the rate of change of the real exchange rate (which translates into about a 14 percentage points increase in the rate of appreciation) leads to an over 1 percentage point increase in the growth rate of domestic output within the year. Although one year later the effect reverses partially, the level of real GDP remains above baseline for several years. This implies that devaluations tend to be contractionary, at least in the short run, although note the caveats below with respect to this result. The real exchange rate shock explains about a fifth of domestic output growth movements (table 1), roughly as much as the

\footnotetext{
${ }^{14}$ This is consistent with the results for the ASEAN countries reported in Ahmed and Loungani (1998). However, in the newly industrialized Asian economies of Hong Kong, Korea, Singapore, and Taiwan that study finds a bigger role for external factors in explaining domestic output movements (about 35 percent).
} 
three external factors put together.

We emphasize two caveats with respect to the above results. First, the sample period covers a mix of exchange rate regimes. The effects of shocks, especially exchange rate shocks, may well differ across exchange rate regimes. A discrete large depreciation of the currency in a fixed exchange rate regime may be inherently a different type of change than small depreciations that might be seen more frequently in floating rate periods. For example, in failed fixed exchange rate regimes, devaluation shocks could well be accompanied by domestic austerity measures and capital outflows that often characterize periods of crises. Moreover, in the collapse of a fixed exchange rate regime, while our measured shocks may capture the "final straw that broke the camel's back" as a particular shock, there is no easy way to capture which of the past shocks led to an accumulation of pressures on the currency which actually made the "final straw" final.

The second caveat is that we have used a limited set of external variables. If there are external factors not captured by these variables, or their interactions with the other variables in our system, the effects of such "omitted" external factors could appear in what we have labeled the domestic shocks.

The remaining results relevant to Question 2 are the responses to a domestic output shock, displayed in figure 5. This shock raises the level of real GDP for about two years, suggesting persistence. However, it does not have much of an effect on the real exchange rate, partly because the output shock is constrained to have a zero contemporaneous effect on the real exchange rate, as part of the identification restrictions. The response of the price level and inflation is negative in the short run, suggestive of an "aggregate supply shock" interpretation of the output shock; an aggregate supply shock would tend to decrease prices, all else equal, whereas an aggregate demand shock would increase prices.

To sum up, although the external shocks we model are significant determinants of domestic output growth, their contribution is relatively small (about 20 percent) compared with the contribution of what we label domestic shocks (about 80 percent), which, admittedly, could 
possibly include relevant external shocks that we have omitted. The results indicate that recessions in these Latin American countries appear to have been caused mostly by factors other than those which can be captured by changes in terms of trade, foreign output, and U.S. real interest rates. These factors show up as adverse real exchange rate and adverse domestic output shocks in our empirical results, and we presume them to be stemming largely from domestic influences, including domestic fiscal and monetary policies. ${ }^{15}$

Question 3: Historically, have real exchange rate movements in key Latin American countries been important in promoting appropriate adjustments of the economy to external and domestic shocks?

At the outset one should emphasize that the analysis here is limited to the equilibrating role that the real exchange rate has played in the actual historical experience of these countries. As already mentioned, this historical experience consists of a mixture of different kinds of exchange rate regimes, including fixed exchange rate regimes which have had to be abandoned in crisis situations. As such, it is doubtful whether the history of these countries is an entirely ideal testing ground for analyzing the effects of a hypothetical regime switch to a conventional-style floating exchange rate system. ${ }^{16}$ Yet, the historical experience is still relevant to a large degree, as this is the experience that Latin policy makers often appear to have in mind when discussing these issues. For example, many of the doubts in the minds of Argentine officials concerning the merits of exchange rate flexibility likely stem from their country's historical experience prior to the present currency peg, an experience in which neither exchange rate adjustment nor the ability to follow an independent monetary policy seemed to have had much of a stabilizing influence on the economy.

Subject to these caveats, a study of the real exchange rate panels in figures 1 through 6 indicates that the real exchange rate does not appear to respond statistically very strongly to any

\footnotetext{
${ }^{15}$ These results and conclusions are consistent with those of Kamin and Babson (1999), who use an early warnings systems approach and divide the "predictive" variables into external and domestic.

${ }^{16}$ This point has recently been forcefully emphasized by Edwards and Savastano (1999), for example.
} 
of the shocks, except its own shock and the price level shock. In response to a positive price shock, there is an appreciation over time of the real value of the currency; this suggests that we have less than one-to-one nominal depreciation of the domestic currency following a positive price shock-at least in the first two years following the change-perhaps reflecting periods of exchange rate pegs in the sample in which the real exchange rate becomes quickly overvalued following price shocks. The contemporaneous responses of the real exchange rate to terms of trade and U.S. real interest rate shocks are almost statistically significant (using 90 percent confidence bands). As might be expected, an improvement in the terms of trade causes a real appreciation of the domestic currency; a rise in U.S. real interest rates causes a real depreciation, consistent with capital outflows from developing countries that are often accompanied by U.S. real rate increases. However, while these responses are plausible, the variance decompositions in table 2 imply that the term of trade and U.S. real interest rate shocks together explain only about 5-12 percent of the fluctuations in the rate of change of the real exchange rate at the zero to twoyear forecast horizon ${ }^{17}$; over 80 percent of fluctuations in the rate of change of the real exchange rate over this horizon are accounted for by the own shock. ${ }^{18}$

What can we conclude about the role of exchange rate adjustments, based on the above results? In order for exchange rate changes to promote appropriate adjustment of the economy to various shocks, not only does the real exchange rate need to depreciate in response to adverse external shocks, but the resulting real exchange rate depreciation itself needs to improve external balances and, in turn, have an expansionary effect on output over time. Our results provide only weak support for the first proposition and go against the second proposition. The lack of strong adjustment of the real exchange rate in response to shocks such as terms of trade shocks, foreign

\footnotetext{
${ }^{17}$ This is in contrast to the results for Asian developing countries found in Ahmed and Loungani (1998); there terms of trade shocks account for 30-50 percent of the movement in real exchange rates. Montiel (1997) also finds strong effects of the terms of trade on real exchange rates in the ASEAN economies.

${ }^{18}$ However, the result that the real exchange rate does not respond much to domestic output shocks is somewhat sensitive to the contemporaneous causal ordering of the real exchange rate vis- $a$-vis domestic output.
} 
output shocks, and even domestic output shocks is perhaps surprising, although in the short run it can possibly be explained by sticky prices and a sample that could be dominated by fixed exchange rate periods.

To sum up, the results suggest that historically, relatively little appropriate adjustment in the economy to external shocks and domestic output and domestic price shocks have occurred through the real exchange rate channel. Thus, the real exchange rate in these economies in the past appears not to have played the equilibrating role that we might expect it to play based on economic theory. However, it is very possible that the real exchange rate plays more of an equilibrating role in flexible exchange rate periods, but this is not being picked up by data from a mixture of exchange rate regimes, including failed experiments with fixed exchange rates that were abandoned only after crisis conditions developed.

\section{Conclusion}

Recently, shortly after the collapse of the Brazilian currency in January of 1999, the Argentine government proposed that serious consideration should be given to the possibility of getting rid of its own currency and completely dollarizing its economy as a conscious policy decision. This has renewed interest in the age-old question of the appropriate form of exchange rate arrangements, particularly for emerging-market countries. The dollarization proposal, especially, is being vigorously debated these days.

What can we conclude, based on the empirical results of this study, about the desirability from a Latin American perspective of moving to very rigid forms of exchange rate systems, including dollarization? If we take these panel results as representative of the responses of Latin American economies to various shocks, the results are mixed, suggesting no strong, clear case against or in favor of rigidly fixed exchange rates. On the one hand, the lack of causality running from the U.S. business cycle to the Latin American business cycles, together with the cyclical fluctuations that would result in Latin America from U.S. real interest rate changes, suggest that rigidity in exchange rate arrangements is not a good idea. On the other hand, the results that real exchange rates have historically not been strongly responsive to external shocks, and that 
devaluations have been contractionary in the short run, seem to indicate that getting rid of exchange rate flexibility may not be as costly as economic theory suggests.

There are, however, some caveats to using a data set that includes failed Latin American fixed exchange rate regimes to make the second conclusion above. Although this paper represents a start, more work needs to be done to sort out whether exchange rate flexibility would prove to be more useful for emerging market economies, if a purer test of the role of floating exchange rates could be conducted. Analyzing and comparing the experience with floating rates of some other commodity exporters, such as Canada, Australia, and New Zealand, might be quite instructive in this regard. We should also caution that many of the arguments we have made based on our results could also be made with respect to the desirability or otherwise of the type of currency board arrangement that Argentina now has in place. However, a currency board-type arrangement is presumably easier to reverse, if and when the costs come to be perceived as outweighing the benefits, than an even more rigidly fixed exchange rate arrangement, such as dollarization, would be. 


\section{References}

Agenor, Pierre-Richard, C. John McDermott, and Eswar S. Prasad. (1999). "Macroeconomic Fluctuations in Developing Countries: Some Stylized Facts," IMF working paper WP/99/35, March.

Ahmed, Shaghil and Prakash N. Loungani. (1998). "Business Cycles in Asia," Board of Governors of the Federal Reserve System, manuscript, June.

Bayoumi, Tamim and Barry Eichengreen. (1994). "One Money or Many? Analyzing the prospects for Monetary Unification in Various Parts of the World," Princeton Studies in International Finance, No. 76, September.

De Gregorio, Jose and Holger C. Wolf. (1994). "Terms of Trade, Productivity, and the Real Exchange Rate," NBER working paper 4807, July.

Edwards, Sebastian and Miguel A. Savastano. (1999). "Exchange Rates in Emerging Market Economies: What Do We Know? What Do We Need to Know?" NBER working paper 7228, July.

Edwards, Sebastian and Carlos A. Vegh. (1997). "Banks and Macroeconomic Disturbances Under Predetermined Exchange Rates," Journal of Monetary Economics, 40, 239-278.

Eichengreen, Barry. (1994). "The Optimum Currency Dilemma," chapter 7 of International Monetary Arrangements for the $21^{\text {st }}$ Century, 79-94, The Brookings Institution.

Eichengreen, Barry and Ricardo Hausmann. (1999). "Exchange Rates and Financial Fragility," manuscript, August.

Fackler, James S. and John H. Rogers. (1995). "Output, Inflation, and Stabilization: A Counterfactual Analysis," Journal of International, Money, and Finance, 14, 619-640.

Frankel, Jeffrey A. and Andrew K. Rose. (1996). "The Endogeneity of the Optimum Currency Area Criteria, NBER working paper 5700, August.

Ghosh, Atish R., Anne-Marie Gulde, Jonathan D. Ostry, and Holger C. Wolf. (1997). "Does the Nominal Exchange Rate Regime Matter?” NBER working paper 5874, January.

Ghosh, Atish R., Anne-Marie Gulde, and Holger C. Wolf. (1998). “Currency Boards: The 
Ultimate Fix," IMF working paper WP/98/8.

Hoffmaister, Alexander W. and Jorge E. Roldos. (1997). "Are Business Cycles Different in Asia and Latin America?" IMF working paper WP/97/9.

Kamin, Steven B. and Oliver D. Babson. (1999). "The Contributions of Domestic and External Factors to Latin American Devaluation Crisis: An Early Warnings Systems Approach,” Board of Governors of the Federal Reserve System, International Finance discussion paper, 645, September.

Kamin, Steven B. and John H. Rogers. (1997). "Output and the Real Exchange Rate in Developing Countries: An Application to Mexico," Board of Governors of the Federal Reserve System, International Finance discussion paper 580, May.

Kenen, Peter B. (1969). "The Theory of Optimum Currency Areas: An Eclectic View." In Monetary Problems of the International Economy, edited by R.A. Mundell and A.K. Swoboda, 41-60, University of Chicago Press.

Larsen, Flemming and Jahangir Aziz. (1997). "ASEAN in the World Economy," in Macroeconomic Issues Facing ASEAN Countries, International Monetary Fund, Washington, DC.

Masson, Paul R. and Mark P. Taylor. (1993). "Currency Unions: A Survey of the Issues." In Policy Issues in the Operation of Currency Unions, edited by P.R. Masson and M.P. Taylor, 3-51, Cambridge University Press.

McKinnon, Ronald I. (1963). "Optimum Currency Areas," American Economic Review 53, 717724 , September.

Mendoza, Enrique. (1995). "The Terms of Trade, the Real Exchange Rate, and Economic Fluctuations," International Economic Review, 36, 101-137.

Montiel, Peter J. (1997) "Exchange Rate Policy and Macroeconomic Management in ASEAN Countries," in Macroeconomic Issues Facing ASEAN Countries, International Monetary Fund, Washington, DC.

Mundell, Robert A. (1961). "A Theory of Optimum Currency Areas," American Economic 
Review 51, 657-64, September.

Reinhart, Carmen M. (1995). "Devaluation, Relative Prices, and International Trade: Evidence from Developing Countries," IMF Staff Papers, 42, 290-312. 
Variance Decompositions for the Latin America Panel Model

Table 1: Variance decomposition of rate of change of output growth

\begin{tabular}{|c|c|c|c|c|c|c|c|c|}
\hline \multirow{3}{*}{$\begin{array}{c}\mathrm{k} \\
\text { (years) }\end{array}$} & \multicolumn{8}{|c|}{$\begin{array}{l}\text { Percentage of the k-step ahead forecast error variance of } \\
\text { domestic output growth explained by }\end{array}$} \\
\hline & \multicolumn{3}{|c|}{ external shocks } & \multicolumn{3}{|c|}{ domestic shocks } & \multirow{2}{*}{$\begin{array}{c}\text { all } \\
\text { external } \\
\text { shocks* }\end{array}$} & \multirow{2}{*}{$\begin{array}{c}\text { all } \\
\text { domesti } \\
\mathrm{c} \\
\text { shocks* }\end{array}$} \\
\hline & $\begin{array}{l}\text { terms of } \\
\text { trade } \\
\text { shock }\end{array}$ & $\begin{array}{c}\text { foreign } \\
\text { output } \\
\text { shock }\end{array}$ & $\begin{array}{c}\text { U.S. } \\
\text { real } \\
\text { interest } \\
\text { rate } \\
\text { shock }\end{array}$ & $\begin{array}{l}\text { real } \\
\text { exch. } \\
\text { rate } \\
\text { shock }\end{array}$ & $\begin{array}{l}\text { domesti } \\
\text { c output } \\
\text { shock }\end{array}$ & $\begin{array}{l}\text { domesti } \\
\text { c price } \\
\text { shock }\end{array}$ & & \\
\hline 0 & 5 & 1 & 9 & 17 & 69 & $0 * *$ & 15 & 86 \\
\hline 1 & 4 & 1 & 15 & 20 & 60 & 1 & 20 & 81 \\
\hline 2 & 6 & 2 & 12 & 16 & 63 & 1 & 20 & 80 \\
\hline 5 & 8 & 5 & 11 & 18 & 55 & 4 & 24 & 77 \\
\hline
\end{tabular}

Table 2: Variance decomposition of the rate of change of the real exchange rate

\begin{tabular}{|c|c|c|c|c|c|c|c|c|}
\hline \multirow{3}{*}{$\begin{array}{c}\mathrm{k} \\
\text { (years) }\end{array}$} & \multicolumn{8}{|c|}{$\begin{array}{l}\text { Percentage of the k-step ahead forecast error variance of rate of change of } \\
\text { real exchange rate explained by }\end{array}$} \\
\hline & \multicolumn{3}{|c|}{ external shocks } & \multicolumn{3}{|c|}{ domestic shocks } & \multirow{2}{*}{$\begin{array}{c}\text { all } \\
\text { external } \\
\text { shocks* }\end{array}$} & \multirow{2}{*}{$\begin{array}{c}\text { all } \\
\text { domesti } \\
\text { c } \\
\text { shocks* }\end{array}$} \\
\hline & $\begin{array}{l}\text { terms of } \\
\text { trade } \\
\text { shock }\end{array}$ & $\begin{array}{l}\text { foreign } \\
\text { output } \\
\text { shock }\end{array}$ & $\begin{array}{c}\text { U.S. } \\
\text { real } \\
\text { interest } \\
\text { rate } \\
\text { shock }\end{array}$ & $\begin{array}{r}\text { real } \\
\text { exch. } \\
\text { rate } \\
\text { shock }\end{array}$ & $\begin{array}{l}\text { domesti } \\
\text { c output } \\
\text { shock }\end{array}$ & $\begin{array}{l}\text { domesti } \\
\text { c price } \\
\text { shock }\end{array}$ & & \\
\hline 0 & 1 & 2 & 4 & 93 & $0 * *$ & $0 * *$ & 7 & 93 \\
\hline 1 & 4 & 2 & 5 & 84 & 0 & 5 & 11 & 89 \\
\hline 2 & 7 & 2 & 5 & 81 & 1 & 4 & 14 & 86 \\
\hline 5 & 11 & 3 & 6 & 72 & 2 & 7 & 20 & 81 \\
\hline
\end{tabular}


Table 3: Variance decomposition of domestic inflation

\begin{tabular}{|c|c|c|c|c|c|c|c|c|}
\hline \multirow{3}{*}{$\begin{array}{c}\mathrm{k} \\
(\text { years })\end{array}$} & \multicolumn{8}{|c|}{$\begin{array}{l}\text { Percentage of the k-step ahead forecast error variance of } \\
\text { domestic inflation explained by }\end{array}$} \\
\hline & \multicolumn{3}{|c|}{ external shocks } & \multicolumn{3}{|c|}{ domestic shocks } & \multirow{2}{*}{$\begin{array}{c}\text { all } \\
\text { external } \\
\text { shocks* }\end{array}$} & \multirow{2}{*}{$\begin{array}{c}\text { all } \\
\text { domesti } \\
\text { c } \\
\text { shocks* }\end{array}$} \\
\hline & $\begin{array}{c}\text { terms of } \\
\text { trade } \\
\text { shock }\end{array}$ & $\begin{array}{c}\text { foreign } \\
\text { output } \\
\text { shock }\end{array}$ & $\begin{array}{c}\text { U.S. } \\
\text { real } \\
\text { interest } \\
\text { rate } \\
\text { shock }\end{array}$ & $\begin{array}{l}\text { real } \\
\text { exch. } \\
\text { rate } \\
\text { shock }\end{array}$ & $\begin{array}{c}\text { domesti } \\
\text { c output } \\
\text { shock }\end{array}$ & $\begin{array}{c}\text { domesti } \\
\text { c price } \\
\text { shock }\end{array}$ & & \\
\hline 0 & 5 & 8 & 18 & 0 & 7 & 63 & 31 & 70 \\
\hline 1 & 4 & 7 & 22 & 1 & 7 & 59 & 33 & 67 \\
\hline 2 & 4 & 7 & 25 & 5 & 6 & 52 & 36 & 63 \\
\hline 5 & 5 & 10 & 23 & 6 & 12 & 45 & 38 & 63 \\
\hline
\end{tabular}

NOTES:

*The contribution of the sum of all external shocks and all domestic shocks may not sum to exactly 100 due to rounding.

**Indicates coefficient is constrained to be 0 as part of the identification assumptions. 


\section{Appendix: Description of Labels and Variables Shown in Figures 1-9}

TOT_GROWTH = Rate of change of the terms of trade, with positive numbers indicating an improvement in the terms of trade and negative numbers indicating a deterioration.

GDP_FOR_GROWTH = Growth rate of foreign output, which is an export-weighted real GDP geometric average of the eight largest trading partners (in terms of exports).

US_RRATE $=$ Level of U.S. real interest rate, which is the nominal 1 year treasury bill rate less the rate of inflation from the last year to the current year.

RER_GROWTH = Rate of change of the real exchange rate, which, for each country, is the Federal Reserve Board's broad trade-weighted 35 country CPI-based index. (Positive numbers indicate a real appreciation and negative numbers indicate a real depreciation.)

GDP_GROWTH = Growth rate of domestic output, which is real GDP.

INFLATION = Rate of change of the price level, which is the consumer price index.

XR_GROWTH $=$ The response of RER_GROWTH less the response of INFLATION. (This measures the path of the rate of change of the nominal exchange rate implied by the responses of the rate of change of the real exchange rate and domestic inflation, keeping constant the foreign inflation rate; positive number indicates a nominal appreciation and negative numbers indicate a nominal depreciation.)

TOT_LEVEL $=$ log-level of the terms of trade, which is an index with base year 1992. (19801997 data are from IDB database; 1998 data are estimated based on World Bank aggregates of terms of trade of oil exporting countries (used for Mexico) and terms of trade of non-fuel primary commodity exporters (used for Argentina and Brazil).

GDP_FOR_LEVEL $=$ log-level of foreign output, which is an index with base year 1992.

RER_LEVEL $=$ log-level of the real exchange rate, which is an index with base year 1992.

GDP_LEVEL $=$ log-level of domestic output, which is an index with base year 1992.

PRICE $=\log$-level of the domestic price level, which is the consumer price index with base year 1992. 
Figure 1

\section{LAT. AM. MODEL: Response to shock to GDP_FOR}
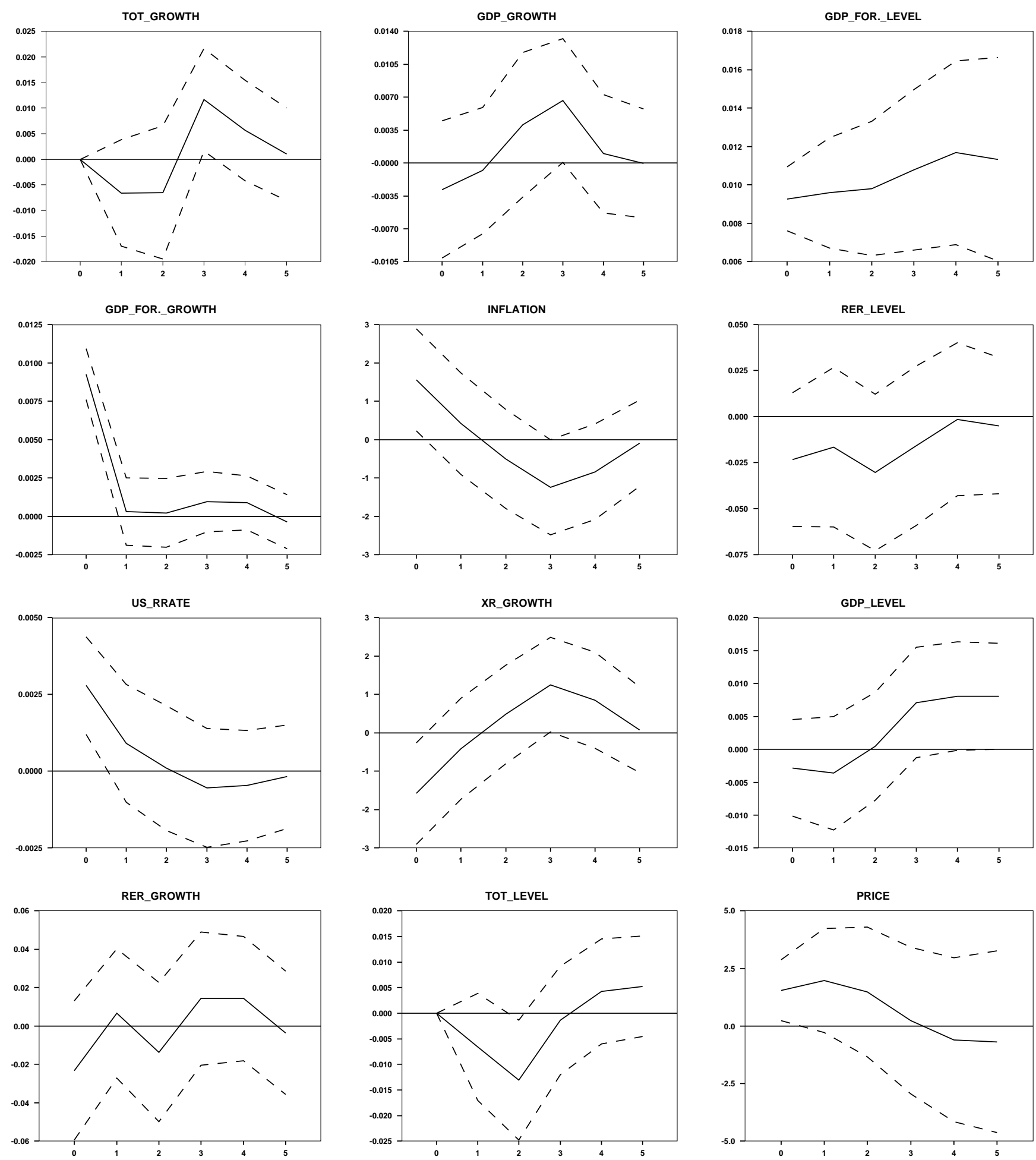
Figure 2

\section{LAT. AM. MODEL: Response to shock to US_RRATE}
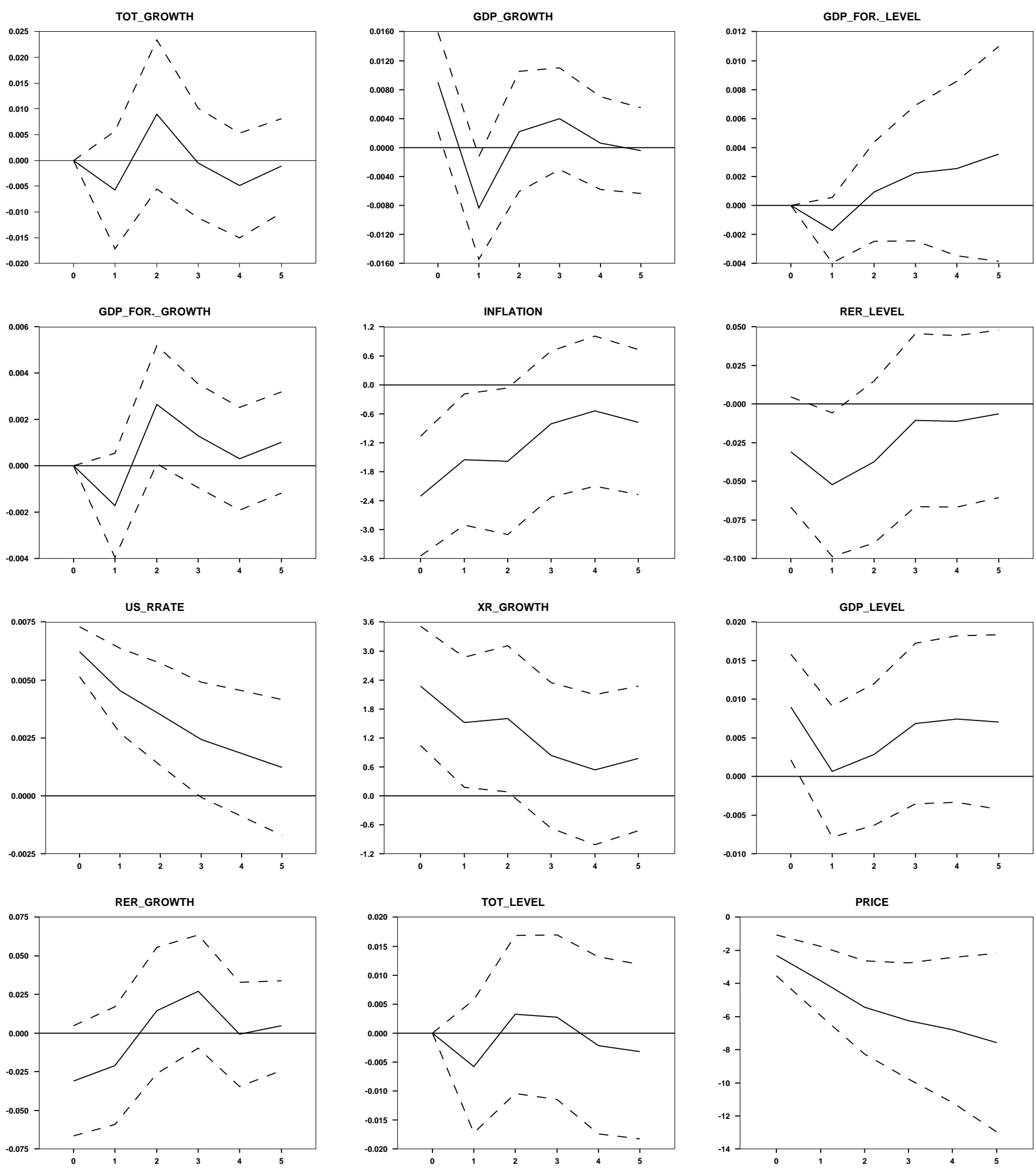


\section{Figure 3}

\section{LAT. AM. MODEL: Response to shock to TOT}
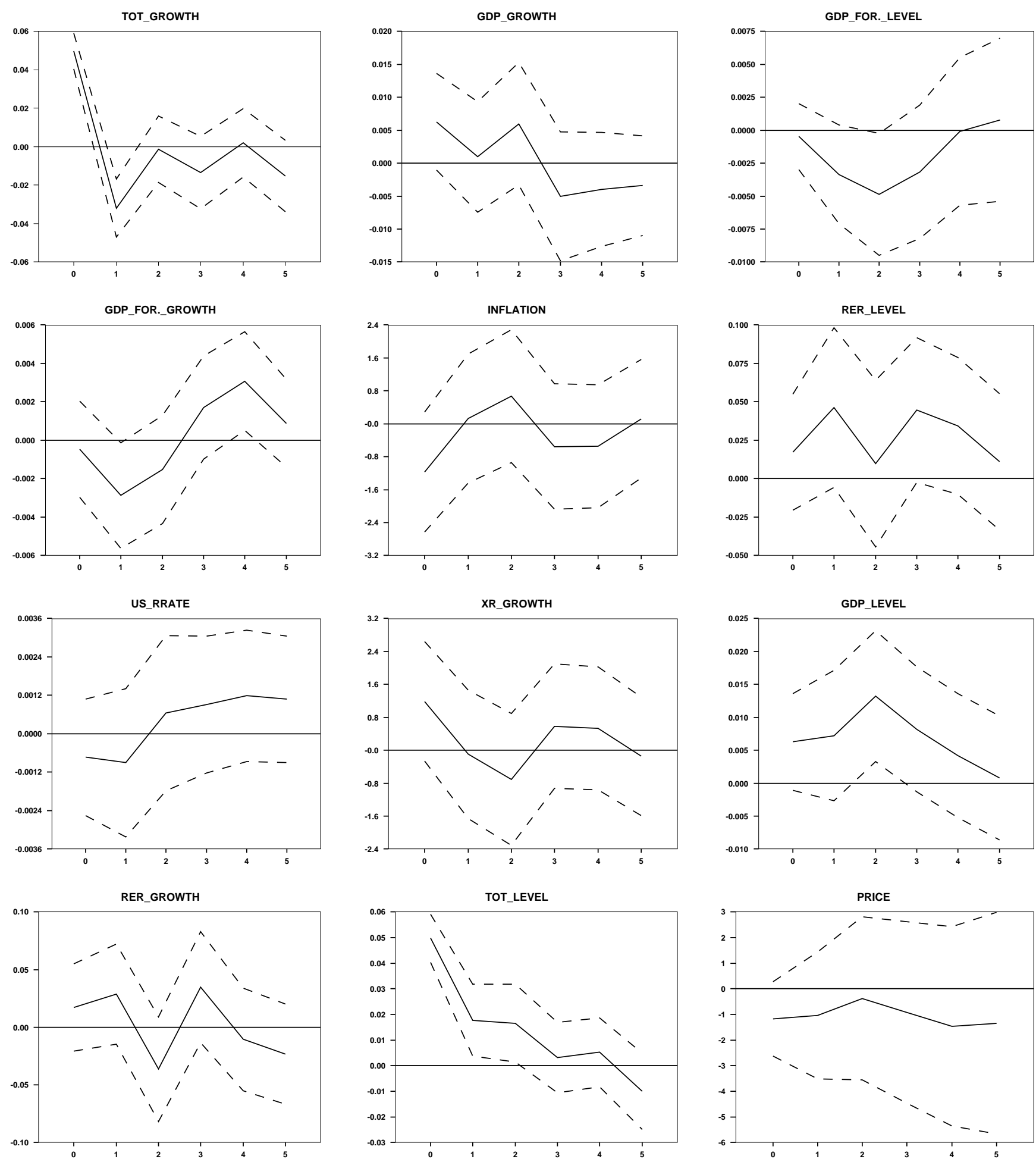
Figure 4

\section{LAT. AM. MODEL: Response to shock to RER}
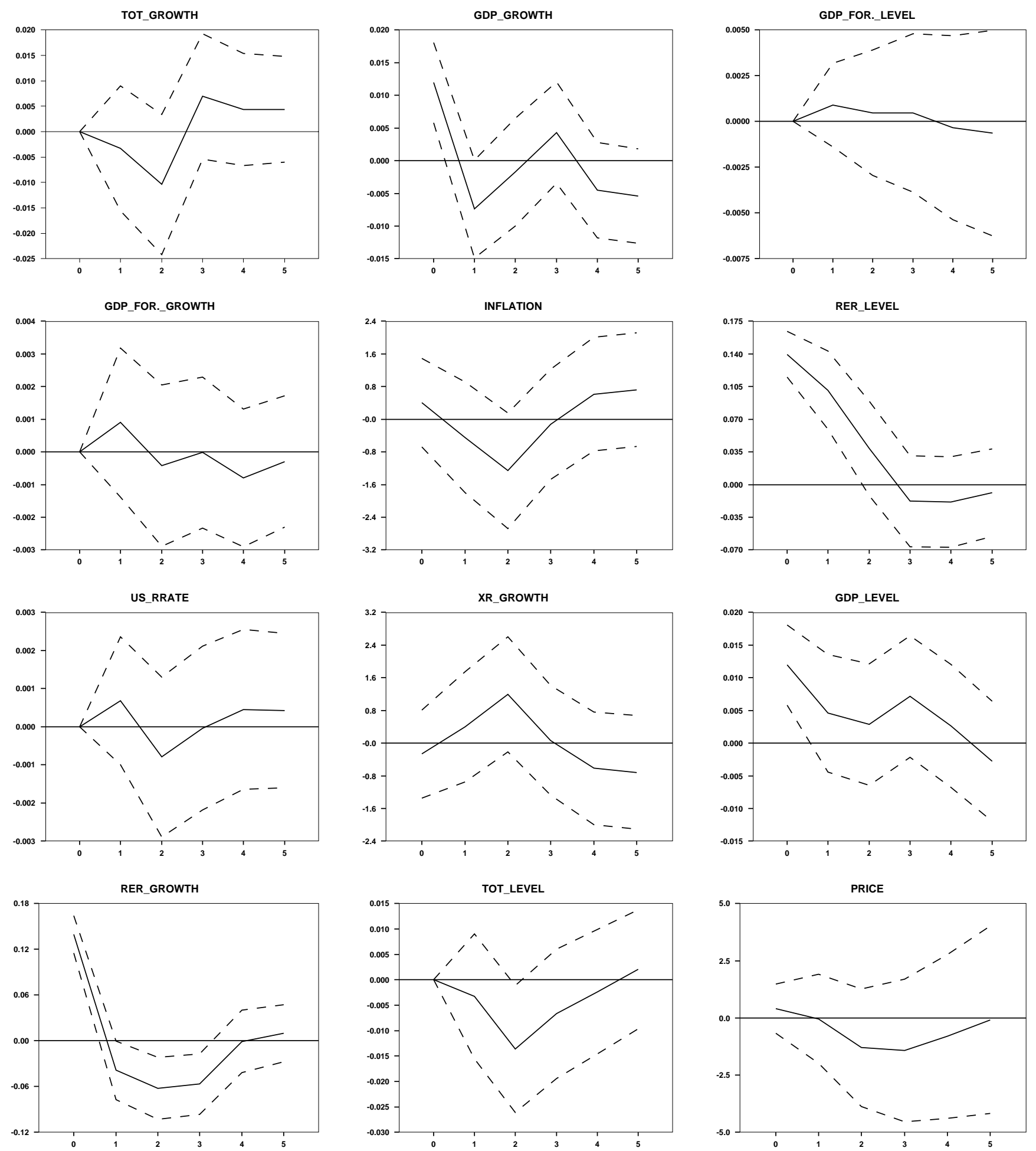
Figure 5

\section{LAT. AM. MODEL: Response to shock to GDP}
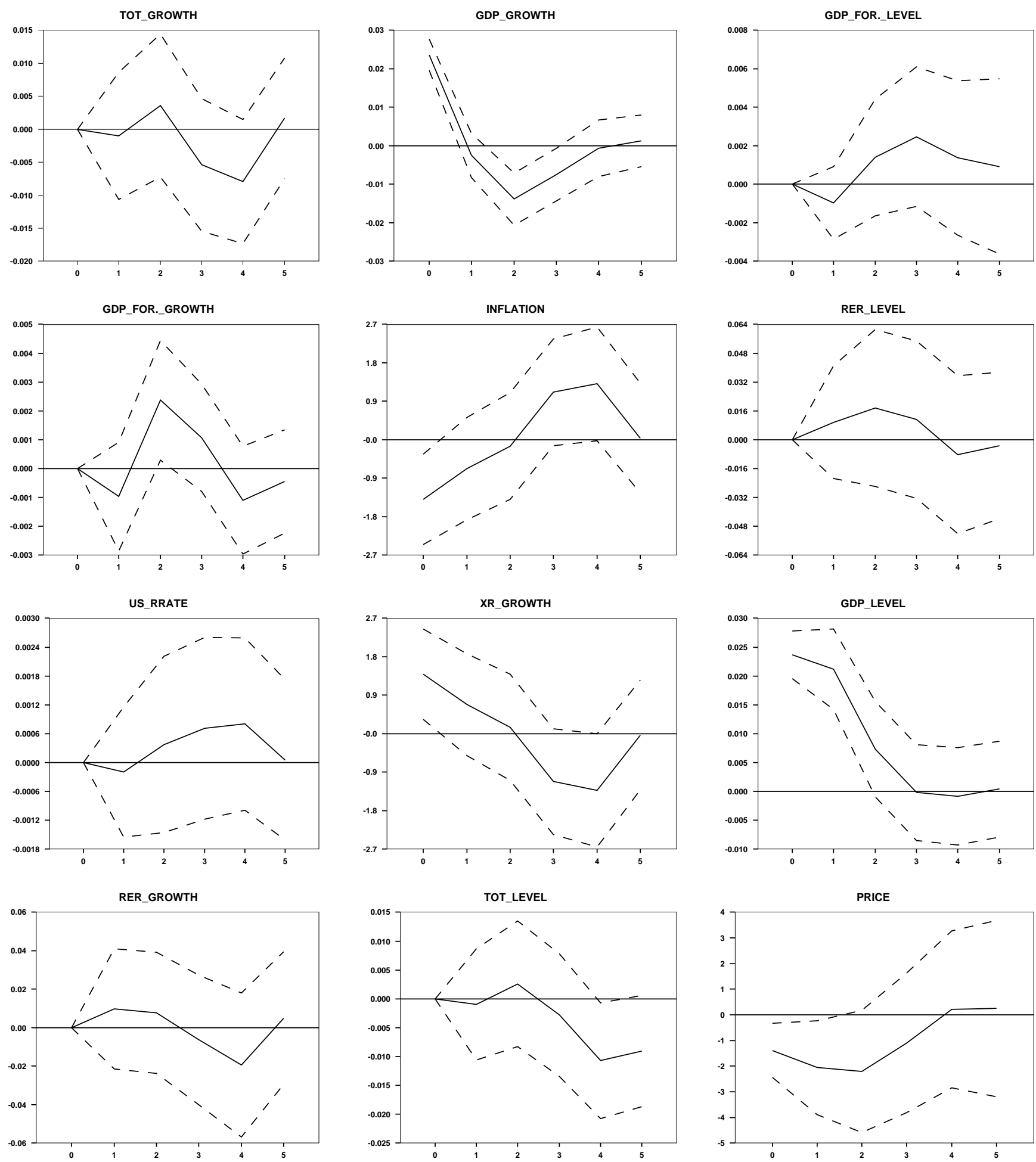
Figure 6

\section{LAT. AM. MODEL: Response to shock to PRICE}
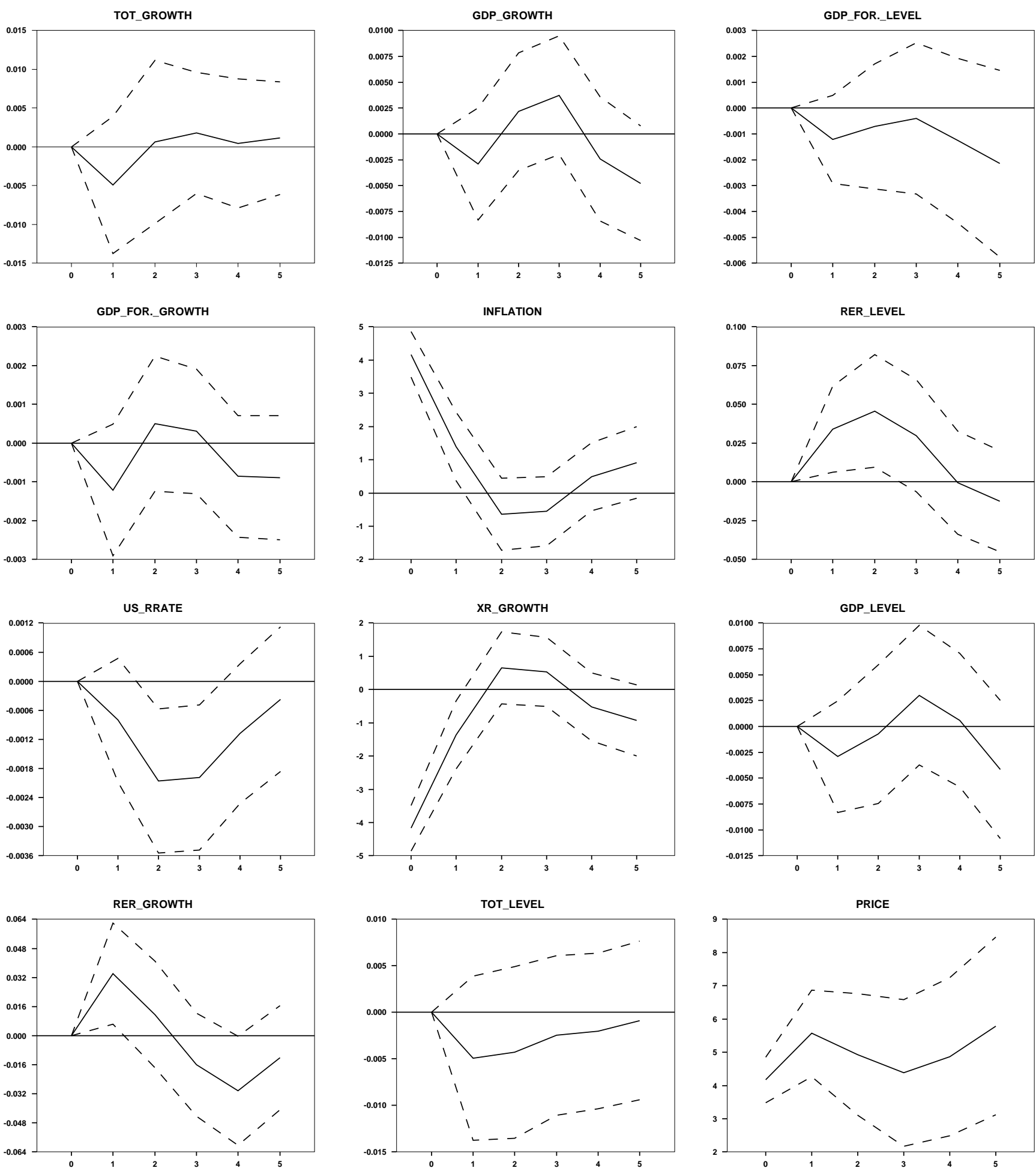
Figure 7: Historical Decomposition: Argentina
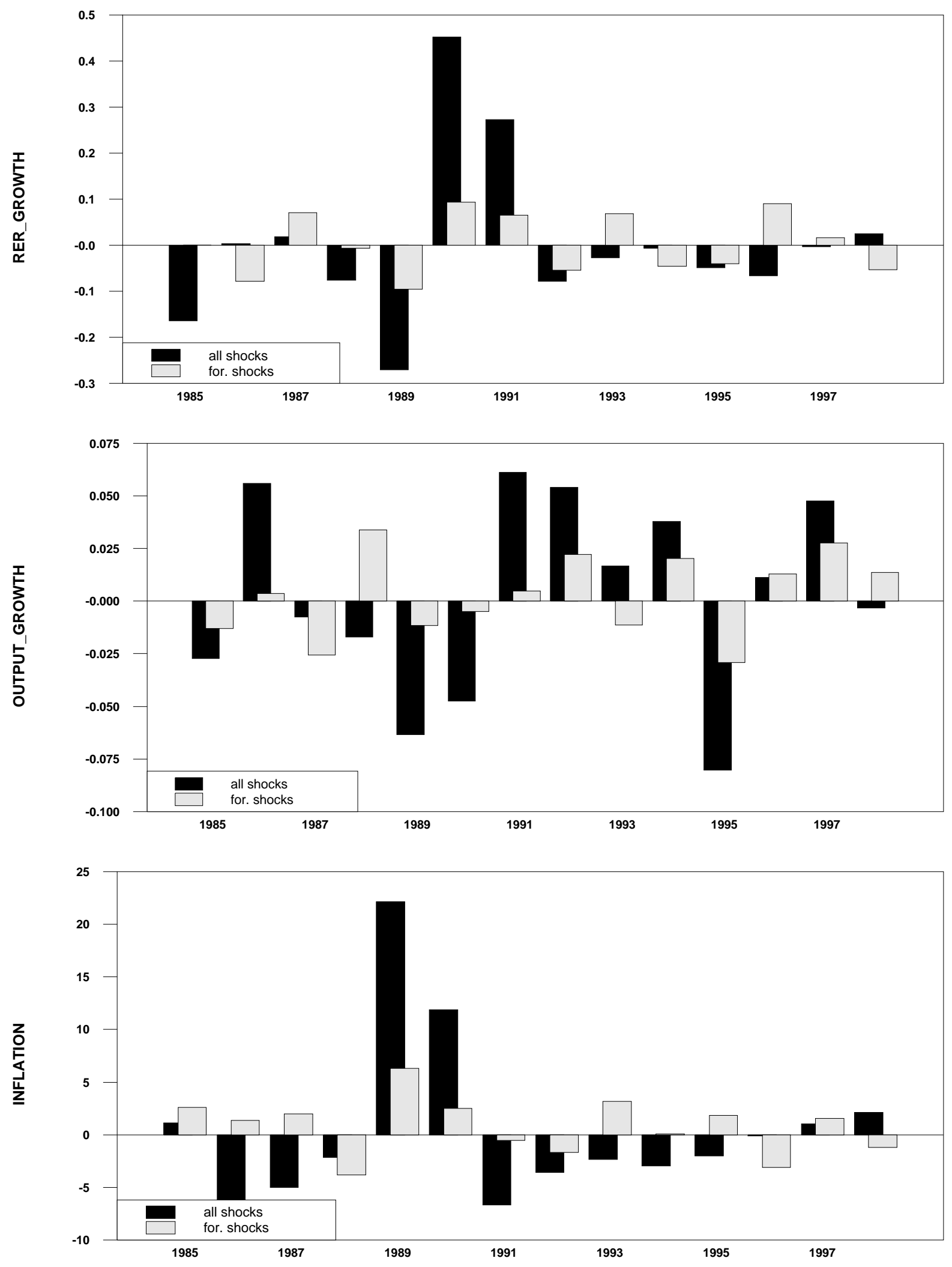
Figure 8: Historical Decomposition: Brazil
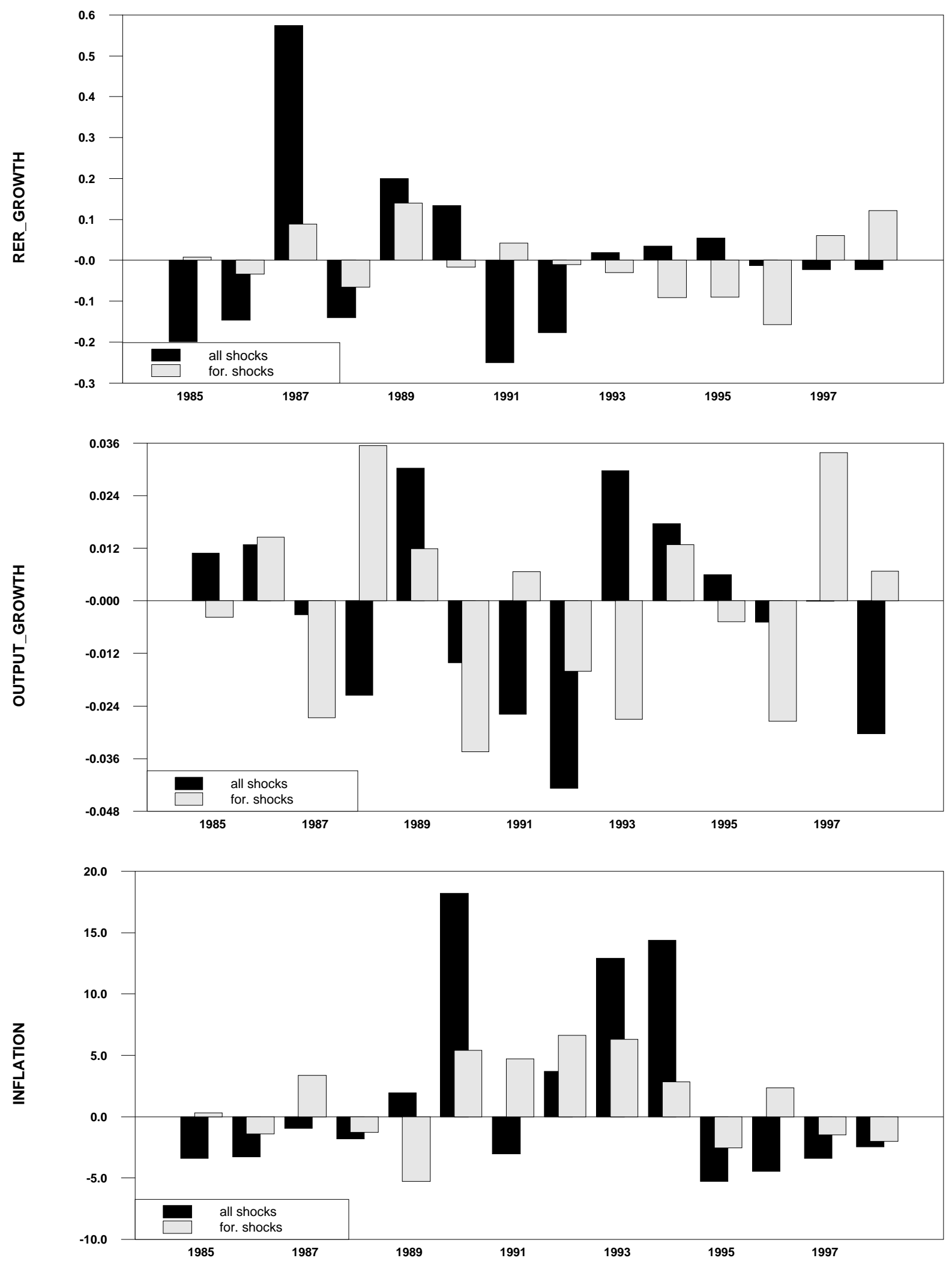
Figure 9: Historical Decomposition: Mexico
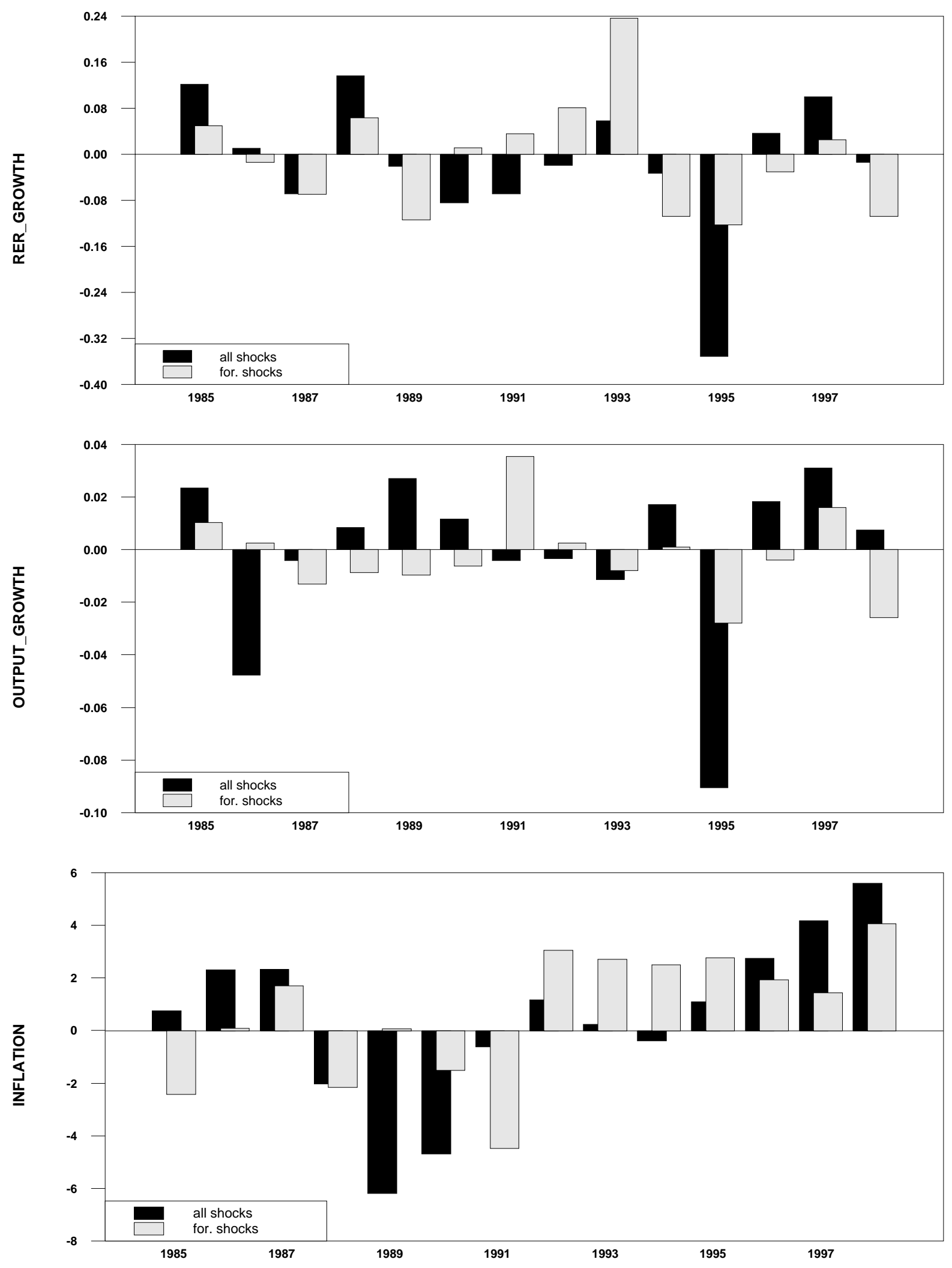


\section{U.S. Real Interest Rate}

1-yr. t-bill rate less inflation over past yr.

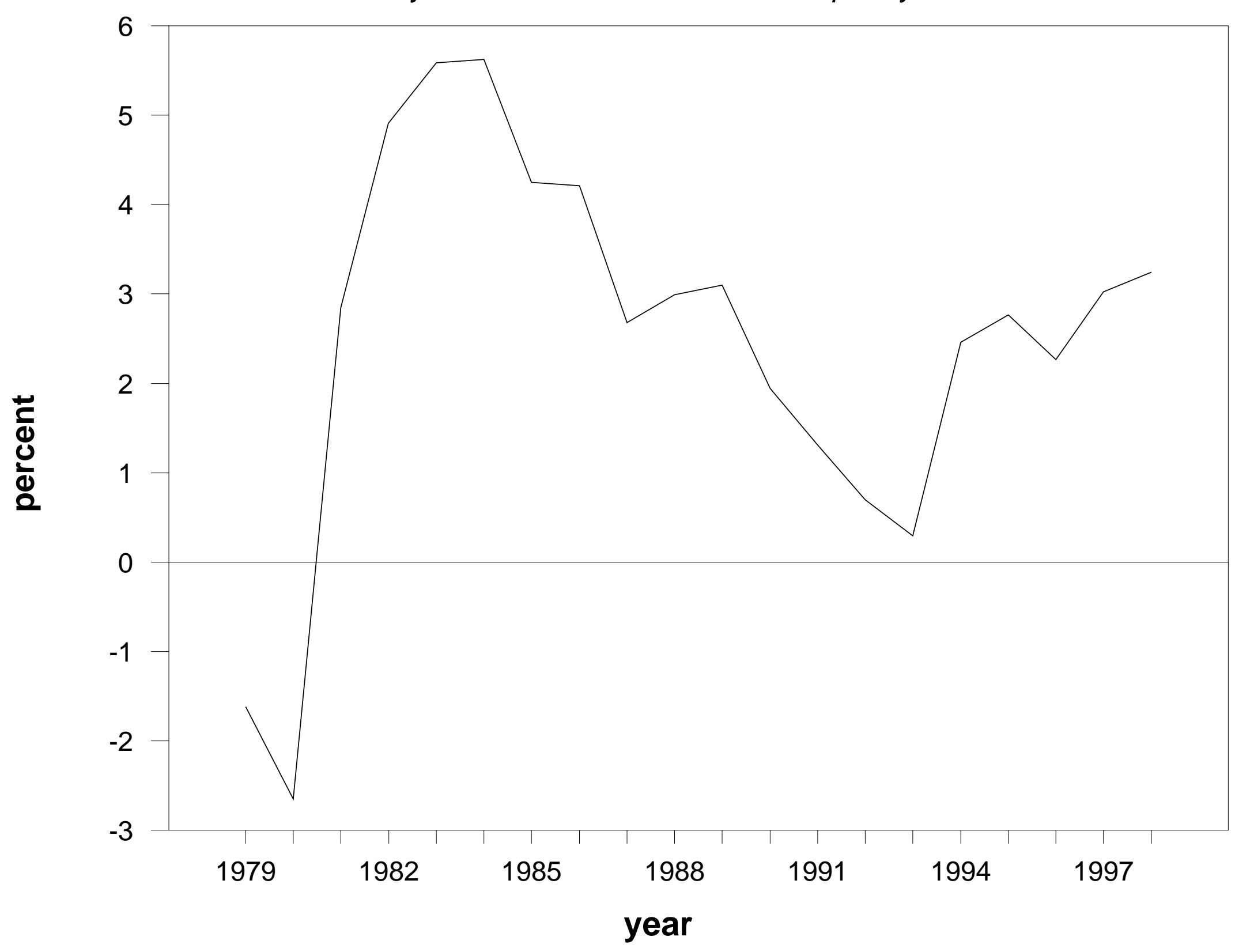




\section{Argentine Variables}

Real Exchange rate

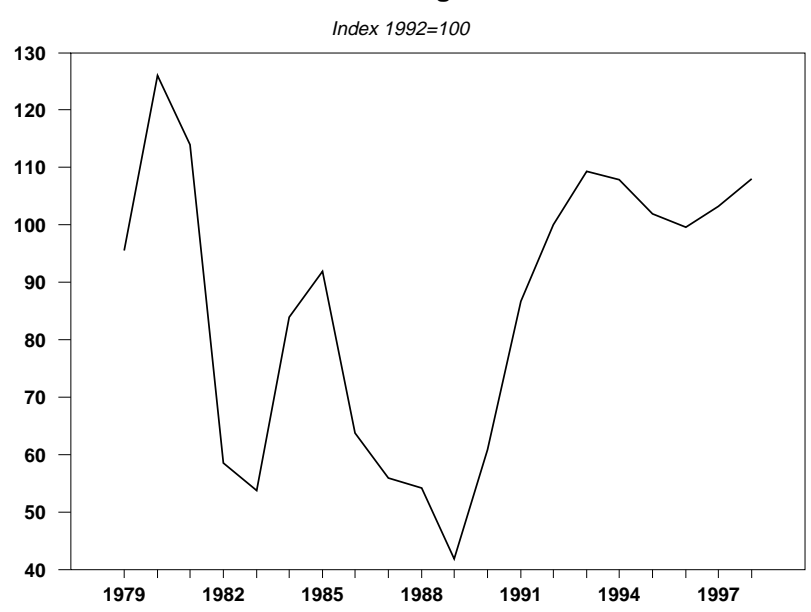

Real GDP

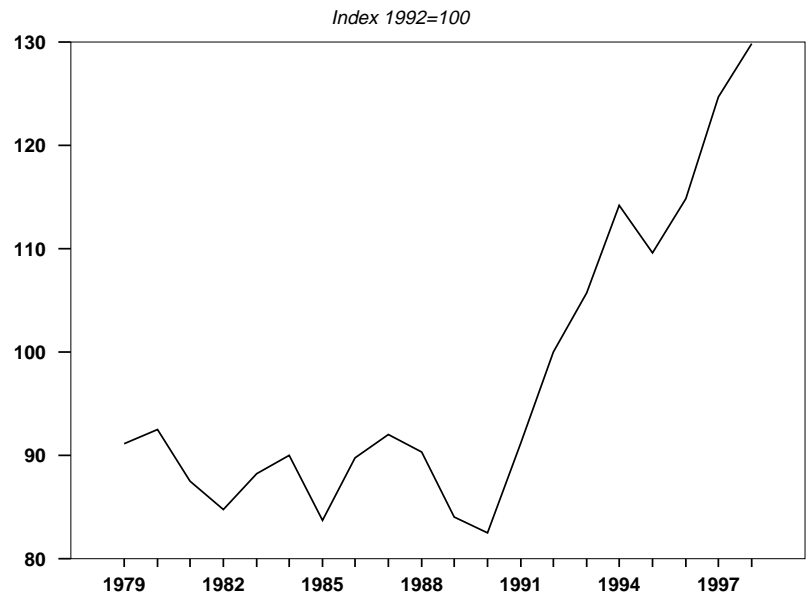

Consumer price index

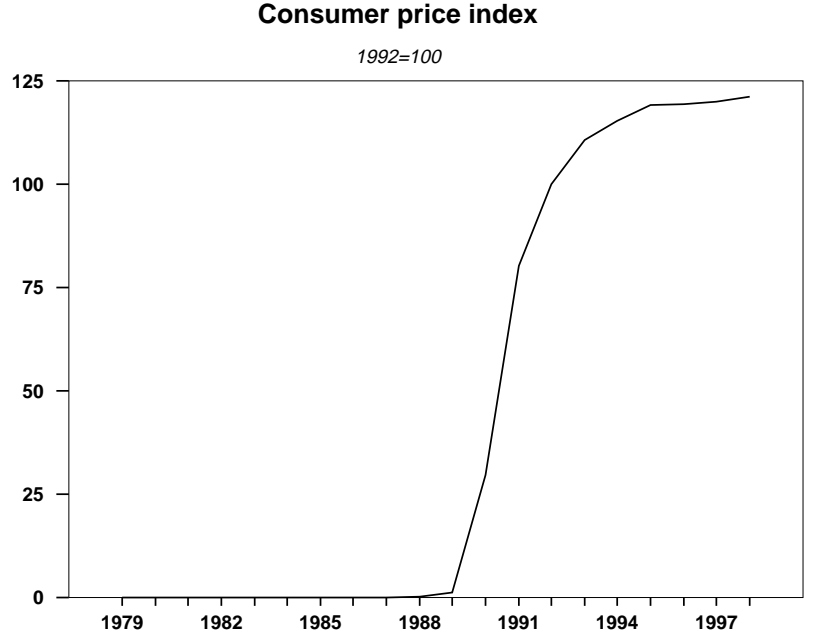

Real Exchange rate

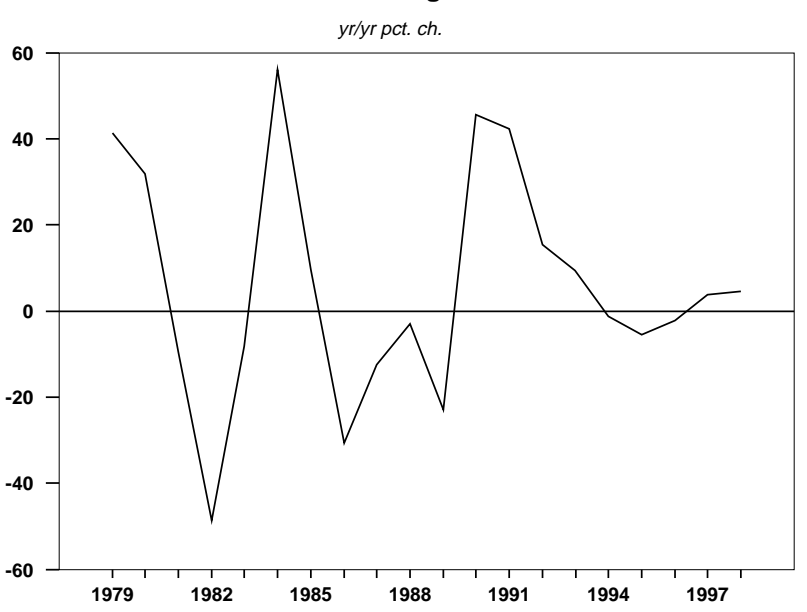

Real GDP

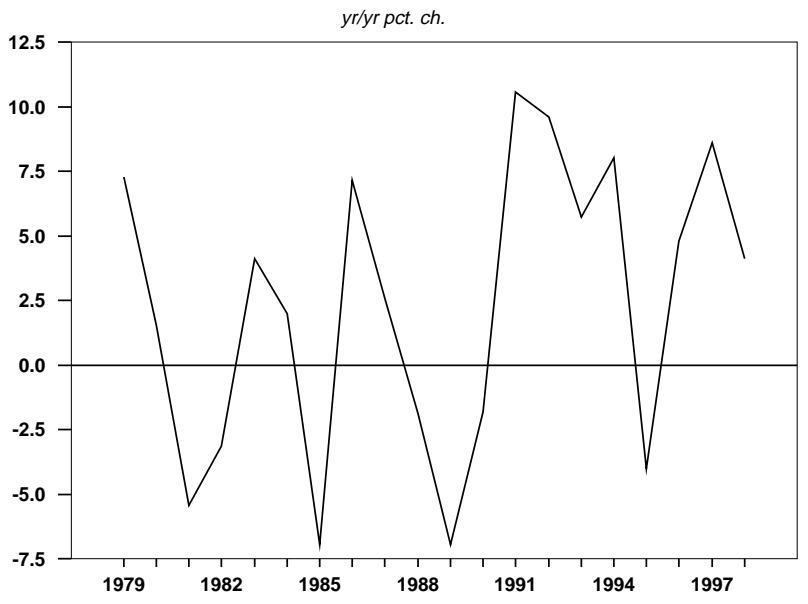

Consumer price index

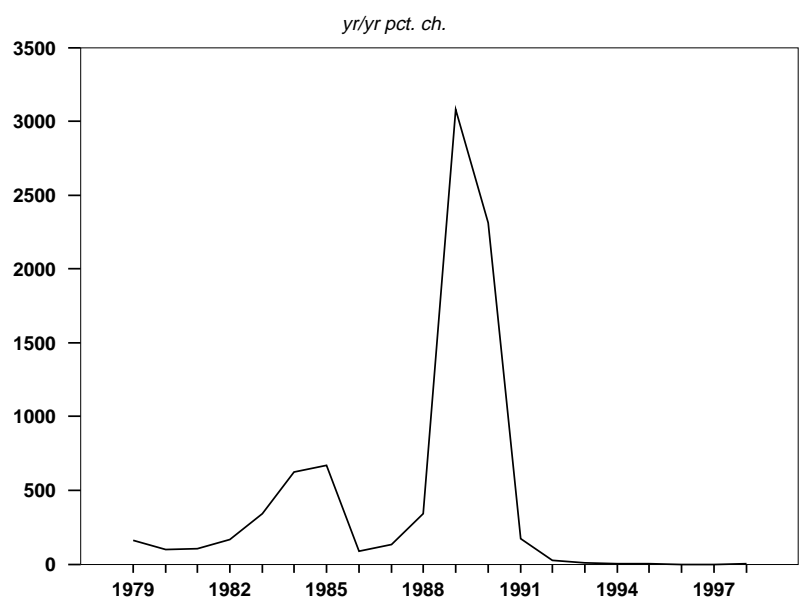




\section{Argentine Variables}

Terms of trade

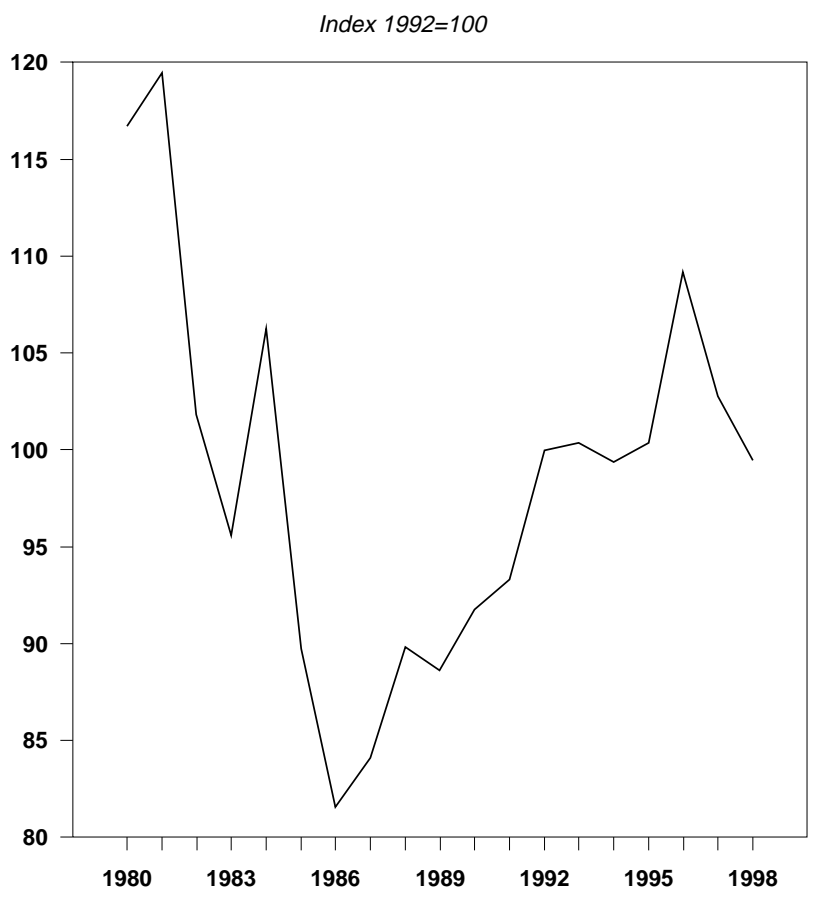

Foreign Real GDP

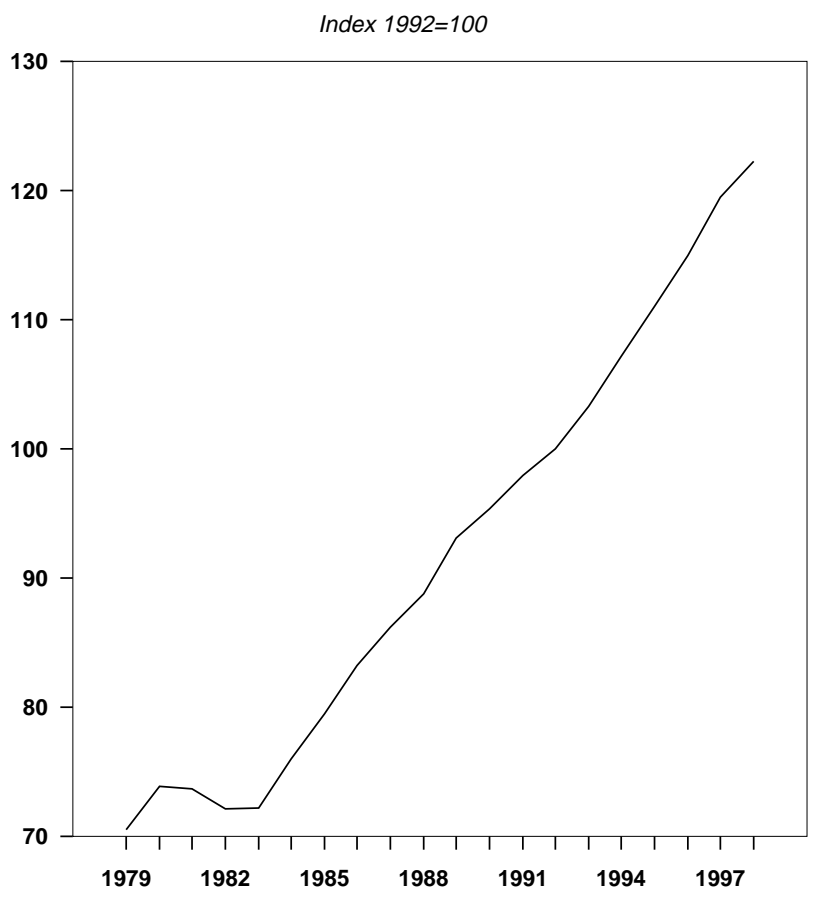

Terms of trade

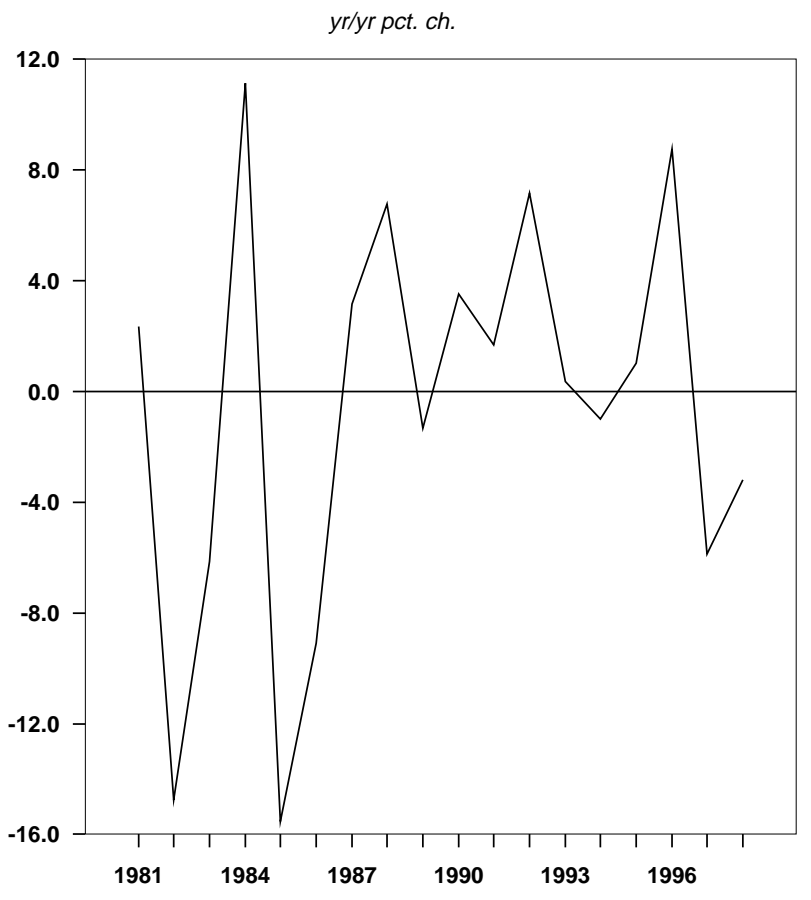

Foreign Real GDP

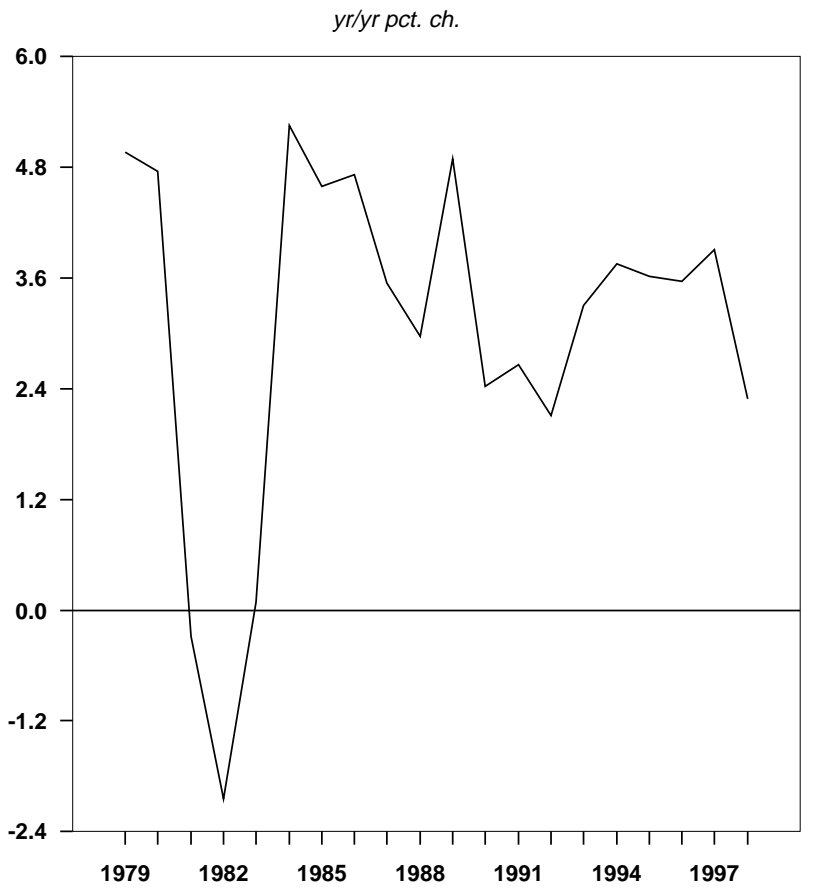




\section{Brazilian Variables}

Real Exchange rate

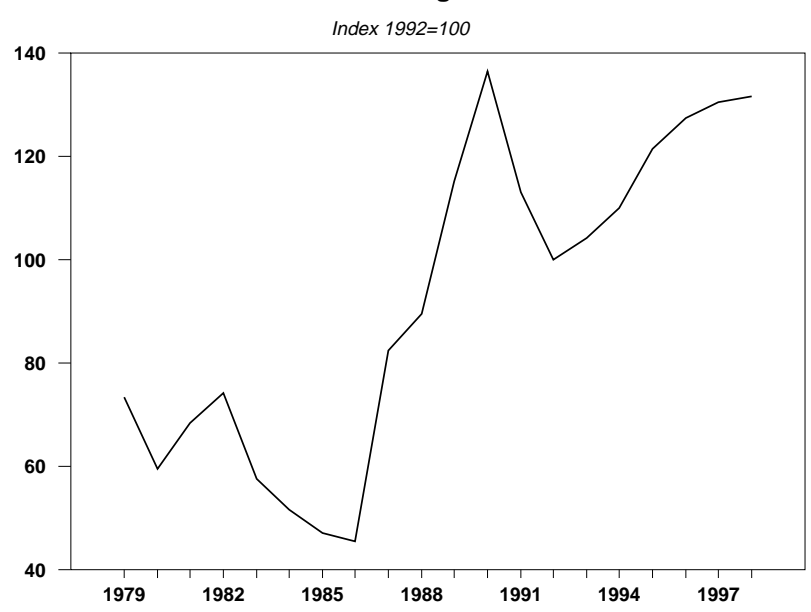

Real GDP

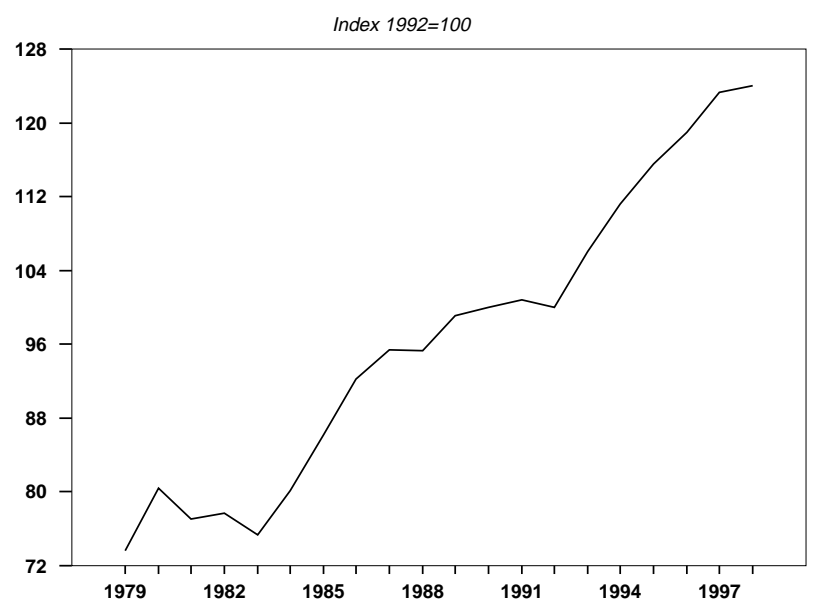

Consumer price index

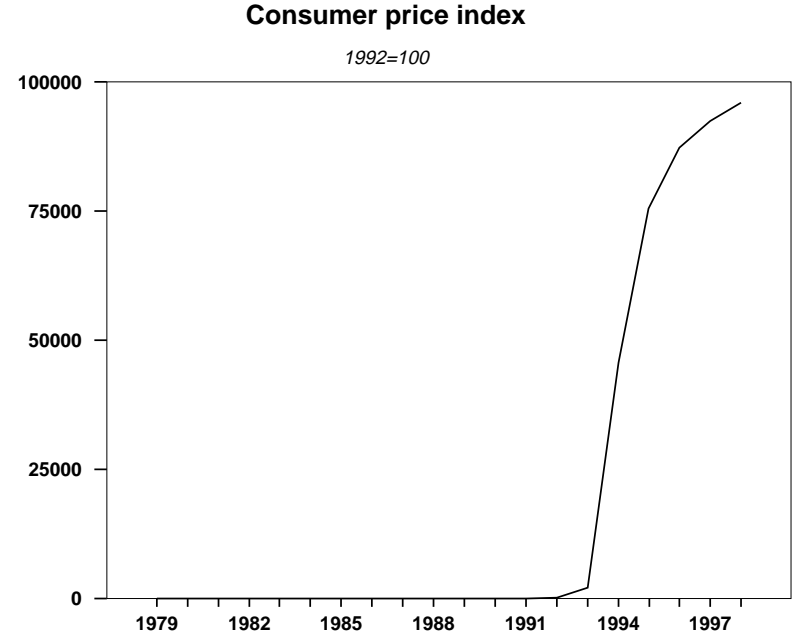

Real Exchange rate

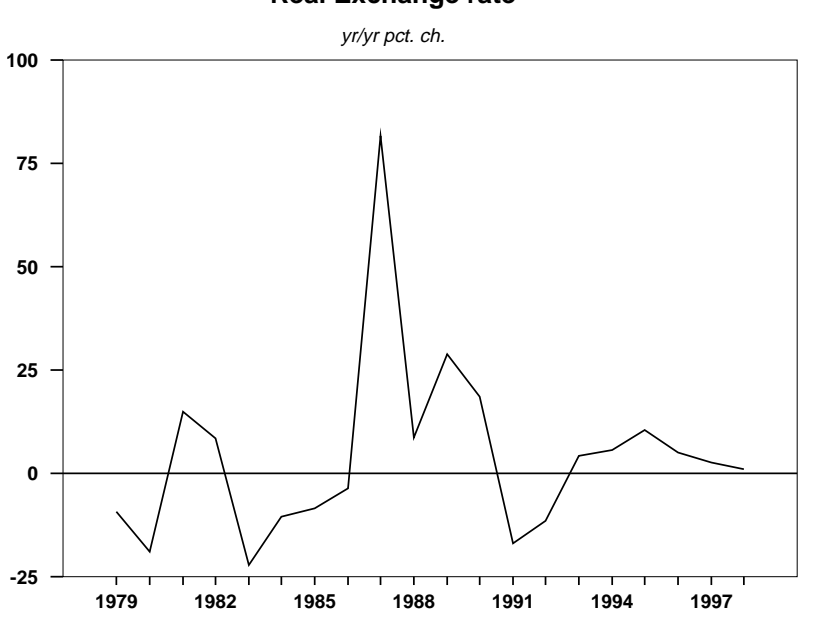

Real GDP

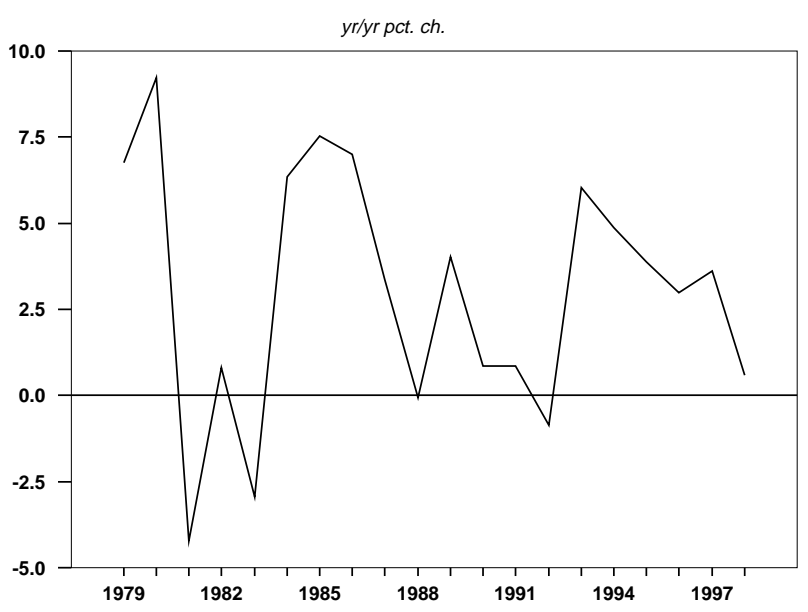

Consumer price index

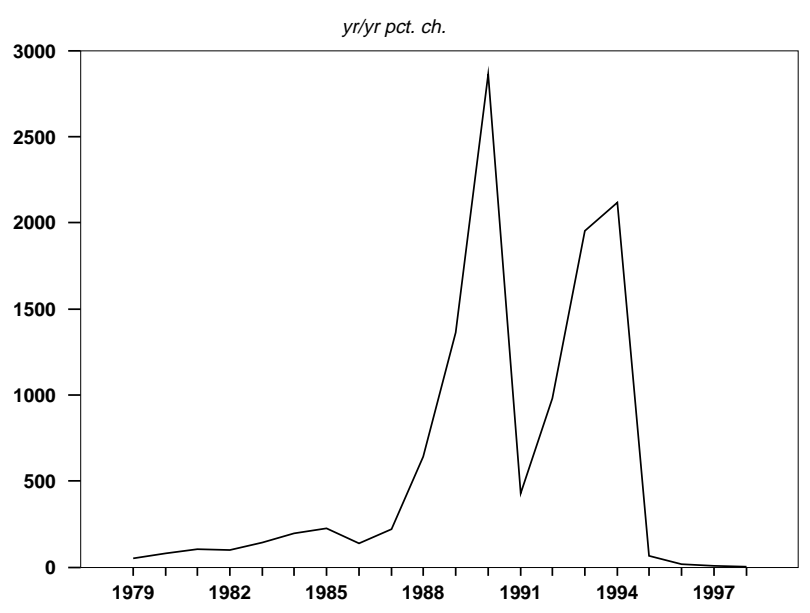




\section{Brazilian Variables}

Terms of trade

Index $1992=100$

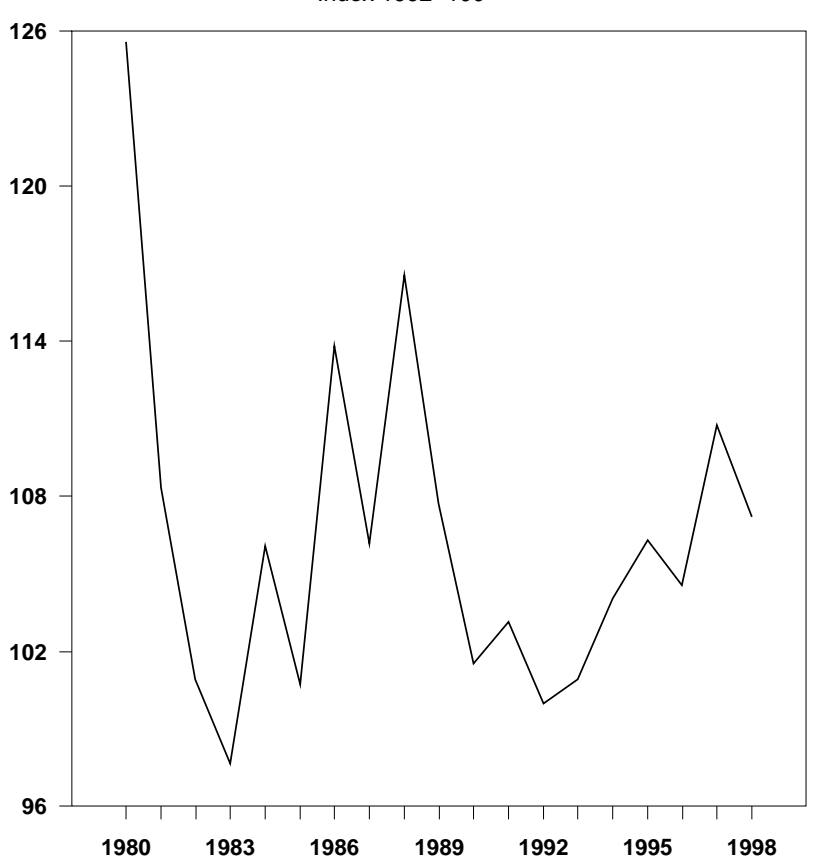

Foreign Real GDP

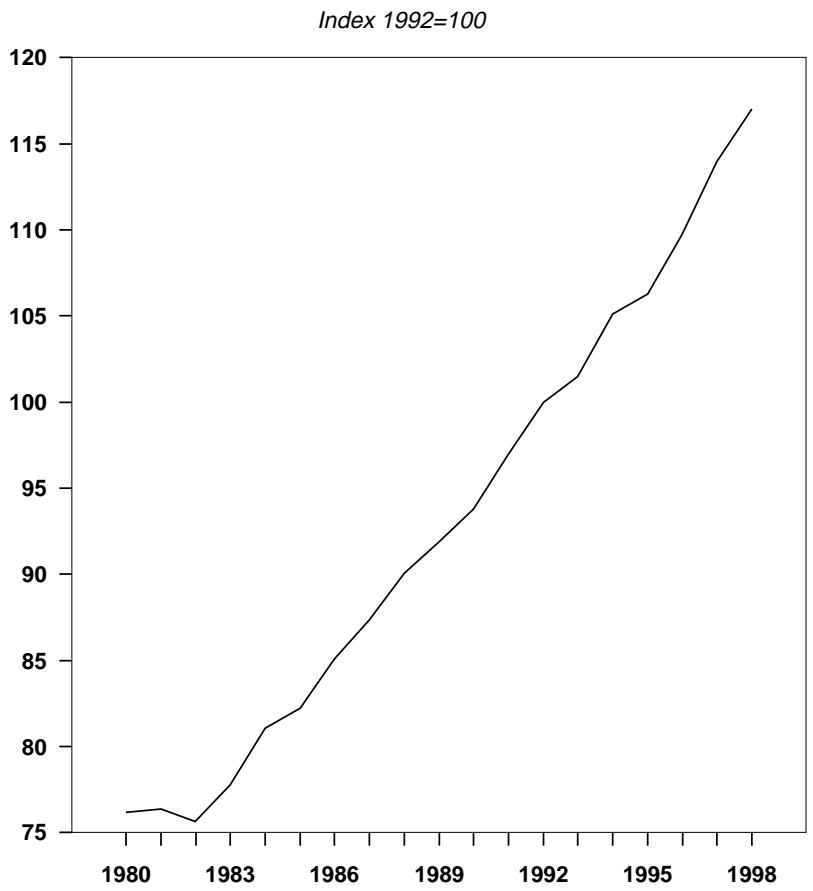

Terms of trade

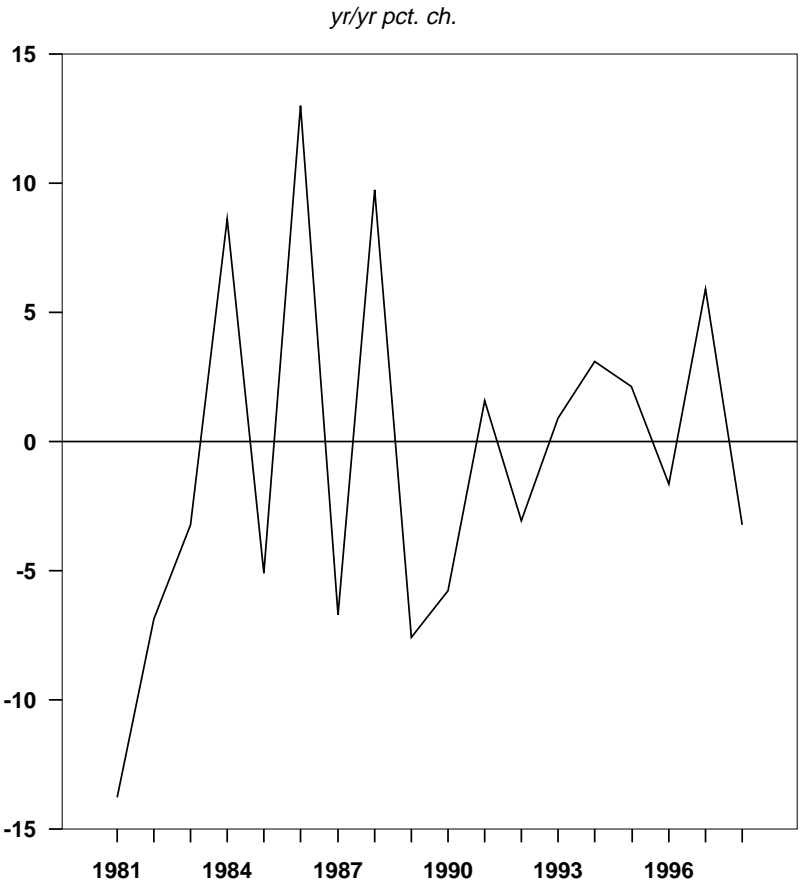

Foreign Real GDP

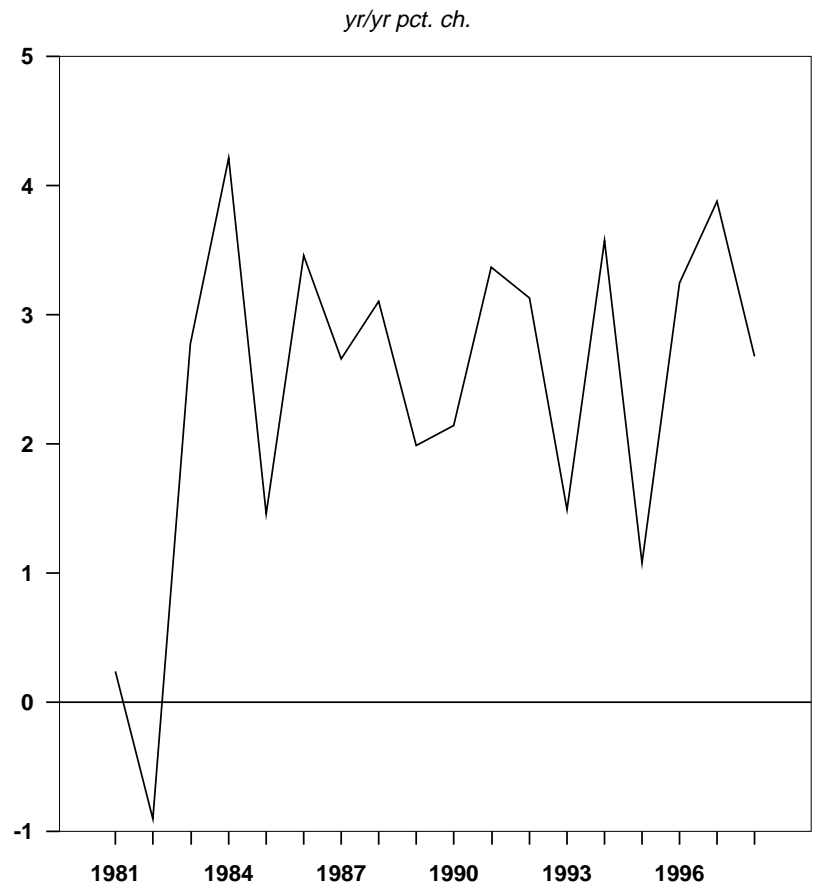


42

Mexican Variables

Real Exchange rate

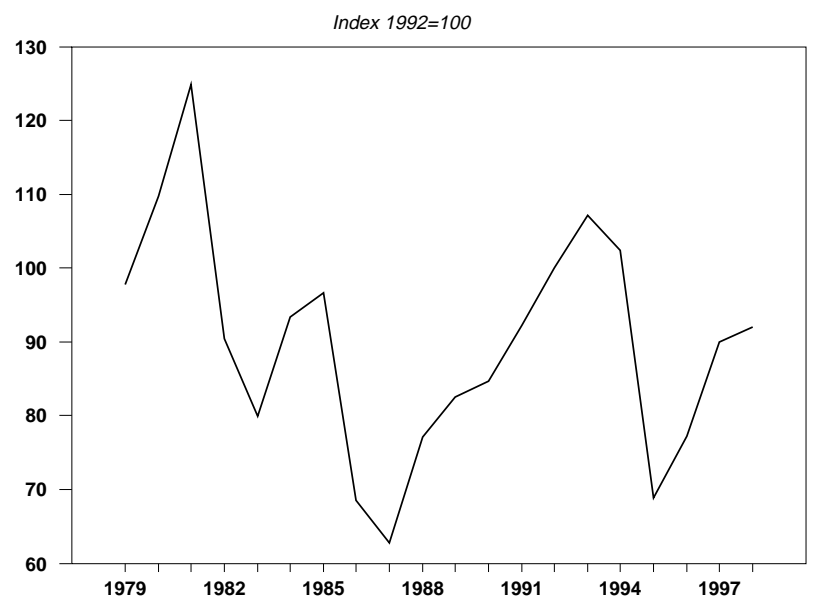

Real GDP

Index 1992=100

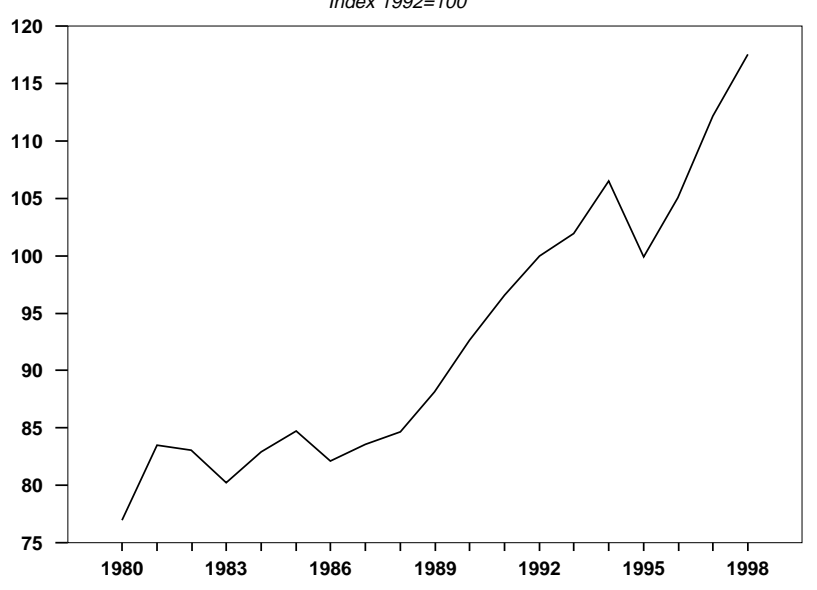

Consumer price index

$1992=100$

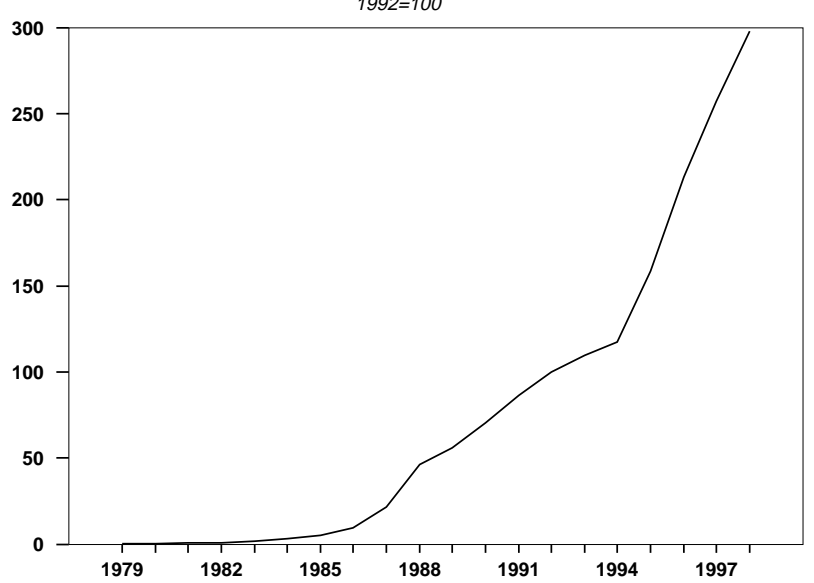

Real Exchange rate

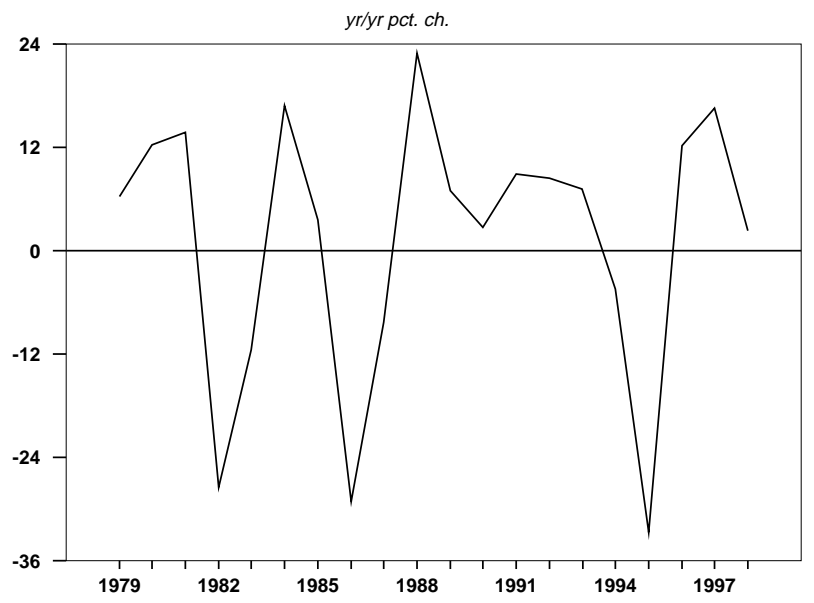

Real GDP

yr/yr pct. ch.

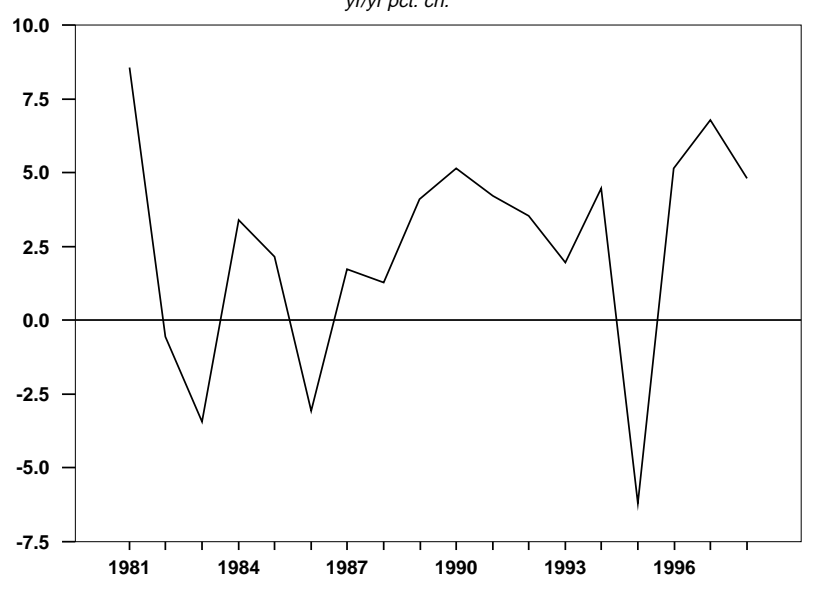

Consumer price index yr/yr pct. ch.

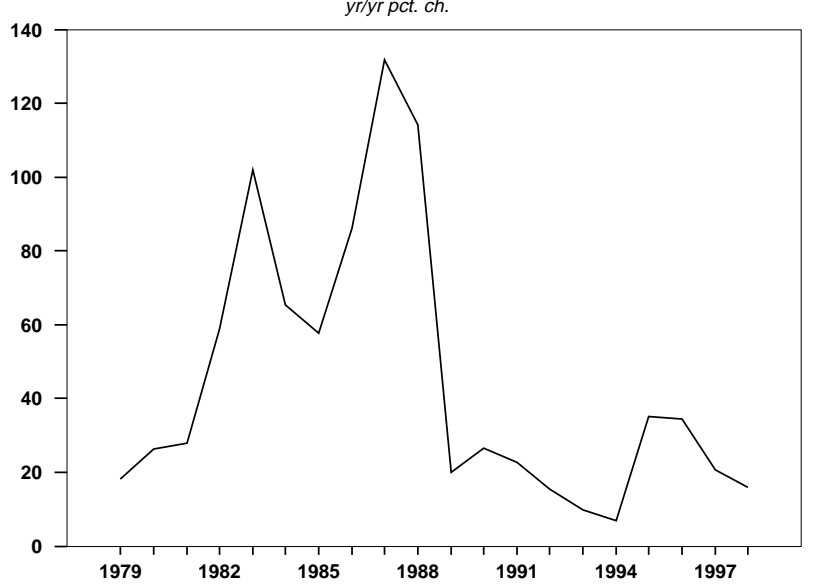




\section{Mexican Variables}

Terms of trade

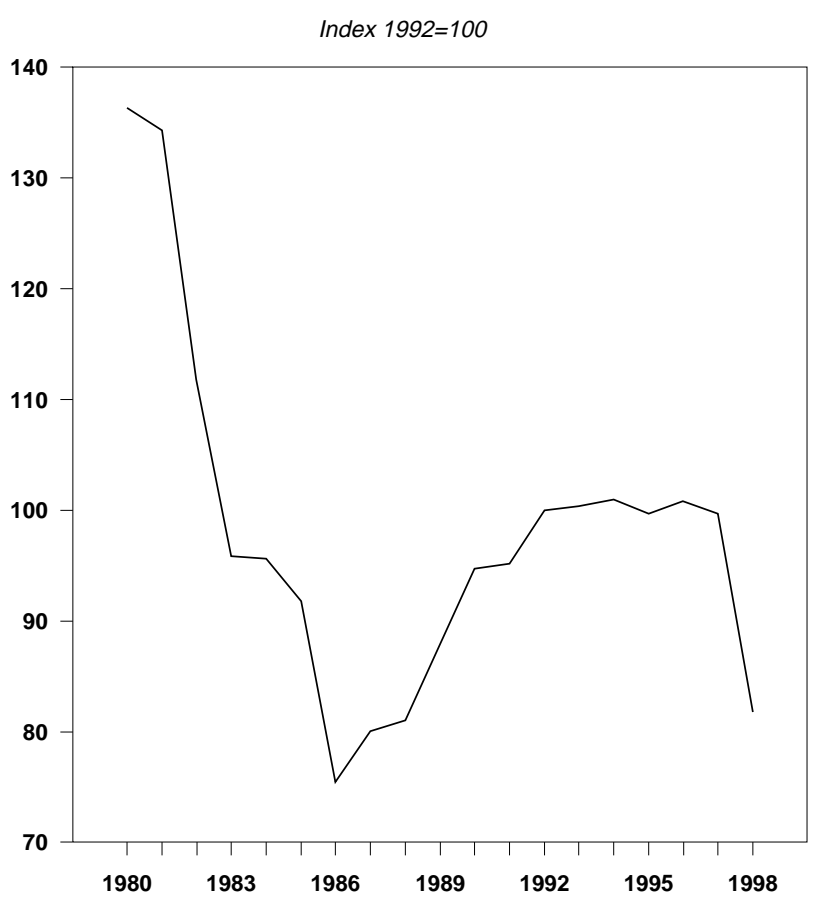

Foreign Real GDP

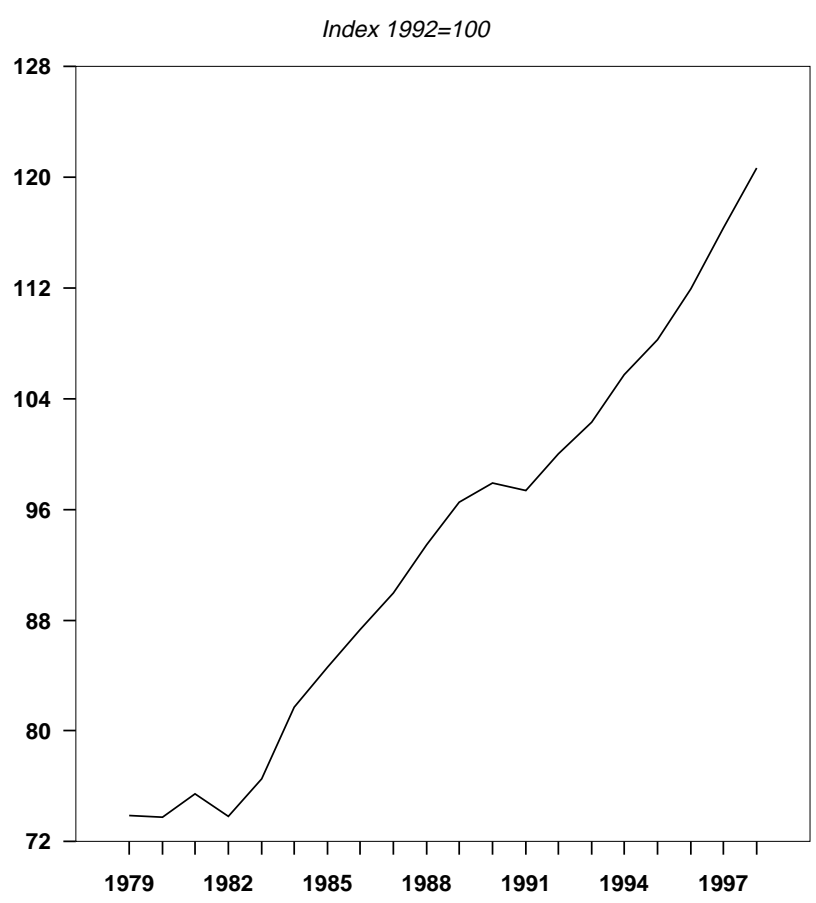

Terms of trade

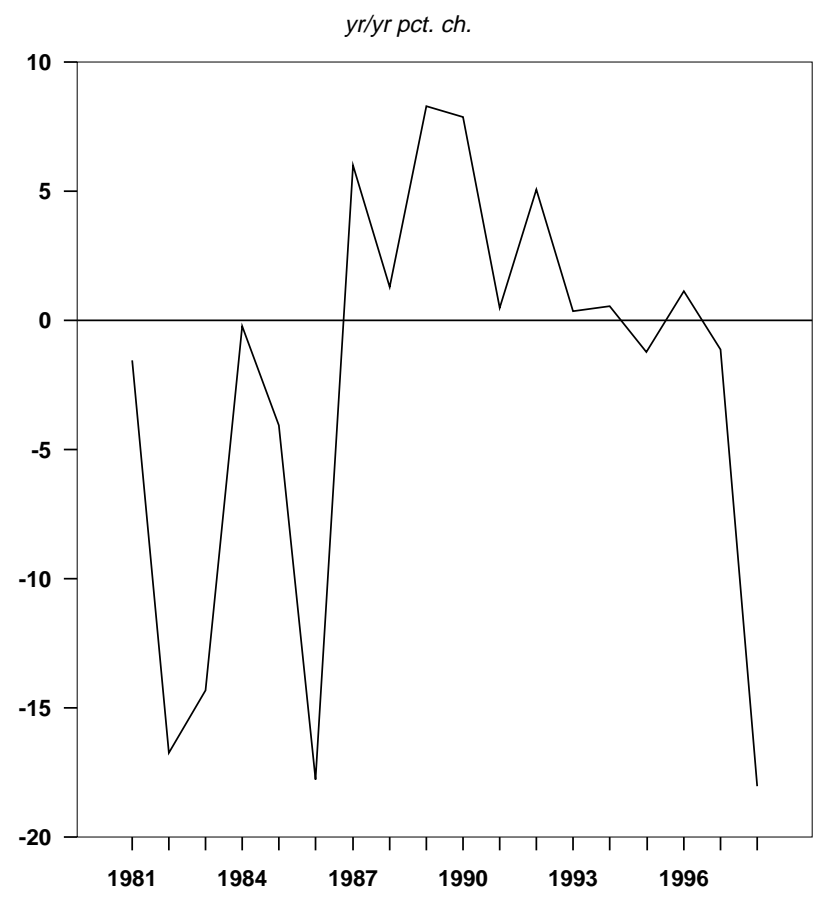

Foreign Real GDP

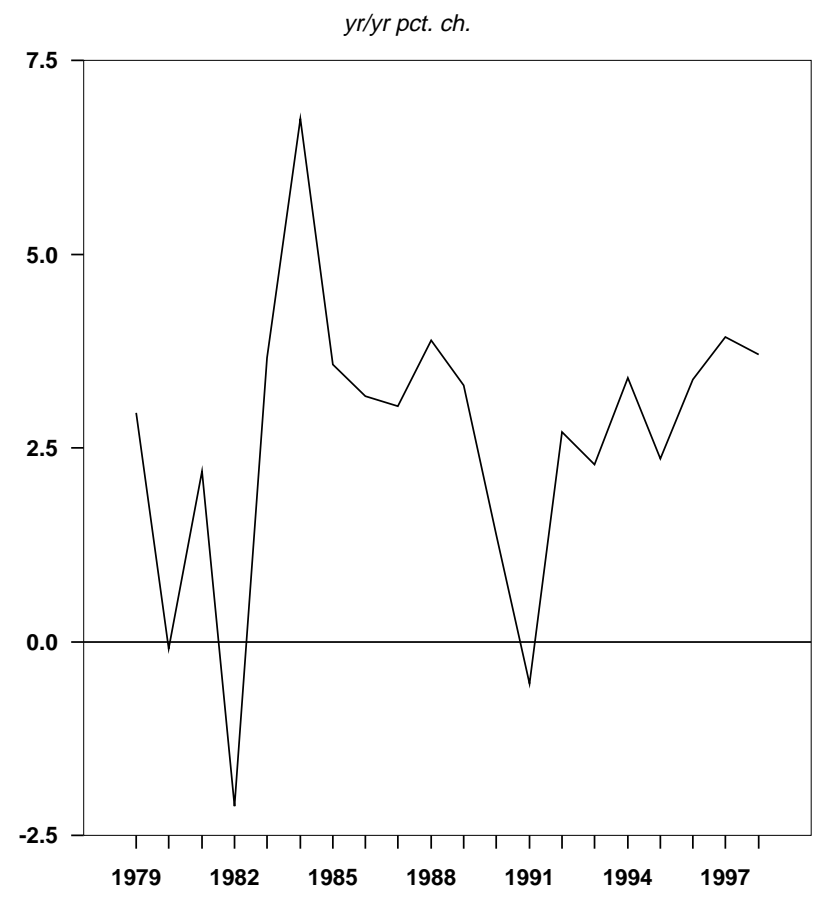

